\title{
Land Reclamation in the Rhine and Yangzi Deltas: An Explorative Comparison, 1600-1800
}

\author{
Guanmian $\mathrm{Xu}^{1}$ (D) Leonard Blussé2
}

Received: 19 December 2017/ Accepted: 22 March 2018/Published online: 16 April 2018

(C) The Author(s) 2018, corrected publication June 2018

\begin{abstract}
In the early sixteenth century, the deltas of Rhine and Yangzi faced comparable ecological crises, but neither of these riverine societies was deterred by the mounting challenges. They independently developed divergent ways to not only defend against the encroaching water, but also reclaim new land from the water.This paper aims to examine the factors in the making of that transformation in these two riverine societies and to ask how they took different paths, why, and what were the implications of that divergence. In asking these questions, particular attention will be paid to the significance of technological and institutional breakthroughs in the Dutch case, such as highly efficient windmills for pumping water, the mapping of cadastral
\end{abstract}

The original version of this article was revised: The corrected authors' names should read as "Guanmian $\mathrm{Xu}$ " and "Leonard Blussé".

This paper was originally presented at the conference, "River Societies: Old Problems, New SolutionsA Comparative Reflection about the Yangtze River and the Rhine” (October 2017, Shanghai), jointly organized by the International Center for Studies of Chinese Civilization of Fudan University (ICSCC) and the Historical Institute of Leiden University, and supported by the China Cultural Media Group Limited and the Jiangsu Provincial Department of Culture. Before, during, and after this conference, we benefited a lot from the constructive comments from our Chinese partners. Among them, particularly, Prof. Xie Shi, Prof. Wu Tao, and Dr. Zhao Siyuan shared their expertise in the water management of Jiangnan with us. After the conference Prof. Petra van Dam, professor of the history of water management of the Free University of Amsterdam, critically reviewed our paper and provided us with many new insights and an up-to-date bibliography for English language readers. We are also thankful that Mr. Lincoln Paine proofread the whole article and gave us some constructive suggestions.

Guanmian Xu

victorhsusea@gmail.com

Leonard Blussé

j.1.blusse@hum.leidenuniv.nl

1 Institute for Area Studies, Leiden University, Lekstraat 112, 2314 VJ Leiden, The Netherlands

2 Professor Emeritus of History of European-Asian Relations, Leiden University, Leiden, The Netherlands 
surveys with triangulation, the centralization of power in the local water boards (heemraden), and the involvement of the financial market. In the Chinese case, we focus on the importance of the developing domestic market, the relationship between state and society in local water management, and the formation of unique local land reclamation organizations.

Keywords China · Dutch Republic · Water management - Great Divergence · Jiangnan

\section{Introduction}

In the early sixteenth century, the deltas of Rhine and Yangzi faced comparable ecological crises. In both regions, the low-lying marshland, which had been reclaimed since the early medieval period, was subject to inundation. The relatively higher area of coastal sand dunes, which protected the inner marshland from the sea, was at various places in the Rhine estuary too weak to keep out the sea during severe storms; in the Jiangnan region of the Lower Yangzi River delta, several ranges of dunes formed such an formidable barrier that they actually hindered the drainage of the excess water from the low-lying hinterland to the sea. In both cases, unstable marine clay banks formed by silt in the estuary of the big rivers were emerging and submerging. Faced with these complex challenges, both societies were forced to maintain and reclaim vast areas of land which was often at or lower than sea level, and to coordinate a process of regional hydraulic management in order to balance potential conflicts among local tenants and landowners.

Yet neither riverine society was deterred by the mounting challenges posed by the encroaching water. From the late sixteenth century, and acting independently of each other, Jiangnan and the Netherlands developed ways and means not only to defend against floods and to drain surface water, but also to reclaim new land from inland lakes and river estuaries. In the case of the maritime provinces of the Dutch Republic, technological breakthroughs and political developments played a big role in inducing urban and commercial entrepreneurship to invest in the systematic drainage of inland lakes and the opening of new polders. In the Yangzi River delta, the rise of the cotton economy during the seventeenth century reversed the balance of power between the lower inland area, the so-called dixiang (低乡), and the higher sand dunes, the so-called gaoxiang (高乡), and further contributed to massive land reclamation on the sandbars of the Yangzi estuary.

This comparative paper aims to examine the factors that contributed to the transformation of the riverine societies of the Rhine and Yangzi deltas and will enquire how and why they took different paths, and what were the implications of that divergence. In asking these questions, particular attention will be paid to the significance of technological and institutional breakthroughs in the Dutch case, such as highly efficient windmills for pumping water, the mapping of cadastral surveys with triangulation, the centralization of power in the local polder authorities (heemraden), and the involvement of the financial market. ${ }^{1}$ In the Chinese case, we

\footnotetext{
1 In order to avoid any misunderstandings it makes sense to point out the correct translation of Dutch terminology in the field of water control:
} 
focus on the importance of the developing domestic market, the relationship between state and society in local water management, and the formation of unique local land reclamation organizations.

By making these comparisons in this experimental paper, we aim to add new perspectives to the usual quantitative and ecological interpretations of the divergence between Western Europe and eastern China. ${ }^{2}$ Focusing on various social and institutional developments in the core areas of the European and Chinese economies, we will discuss how two riverine societies responded to comparable ecological constraints in divergent ways.

\section{The Setting}

The basic structures of the Rhine-Meuse-Scheldt delta (henceforth the Rhine delta) and the delta of the Yangzi River and its tributaries are similar. In both cases, coastal sand dunes accumulated during the long stable period of slowly rising sea levels. Along the seaward side, some weaker sand dunes were buttressed by manmade sea dikes. Inside the dunes, patches of low-lying marshlands had been drained and embanked since the medieval period. Along the riverbanks, clay ridges arose, and in the estuary sandbars emerged, disappeared, and re-emerged elsewhere owing to the interplay between river currents and tidal flows on sedimentation.

In the European case, it has been suggested that from Roman times until the end of the nineteenth century, the sea level rose around $30-50 \mathrm{~cm}$, that is, only about $2 \mathrm{~cm}$ per century. During the past century, the rise has been $15 \mathrm{~cm}$-much higher than the previous average. ${ }^{3}$ During the Holocene, which began around 11,700 years ago, peatforming ecosystems were created behind the buffer of the dunes. By the early Middle Ages, peat bogs of various depths covered virtually all of the lowland zone (Fig. 1).

In the Netherlands, peat land, the main type of soil in the provinces of North and South Holland, extended up to 80 kilometres inland, as far as the country's upland zones. This area was protected by a narrow strip of sand dunes that was occasionally broken by North Sea gales. Between the ninth and thirteenth centuries, this marshland was gradually drained and reclaimed and made fit for agricultural and pastoral purposes. At the outset, the reclaimed peat land was still higher than sea level, but the sponge-like peat, which was about 80 per cent water by volume, began to decompose due to settling and oxidation when the ground water level was purposely lowered to make human habitation possible. In turn, that process caused

\footnotetext{
Footnote 1 continued

Local water boards = Polders; Polder judges/administrators = Heemraden or Kroosheemraden; Regional water authorities/boards/courts = Hoogheemraadschappen; Regional board members/judges/ administrators=Hoogheemraden. Until 1600 or so, the regional water authorities were courts (rechtbanken), after that they developed into boards (besturen) with executive tasks. Therefore, many historians in the field instead of using "boards" prefer the more neutral term "authorities".

${ }^{2}$ Such an approach has been suggested by Andrew Wareham, see Wareham (2006). However, Warenham mostly focuses on the fenlands of northeast Cambridgeshire in Eastern England and devotes only a few paragraphs to developments in Jiangnan and the Low Countries.

3 Borger (1988: p. 525).
} 


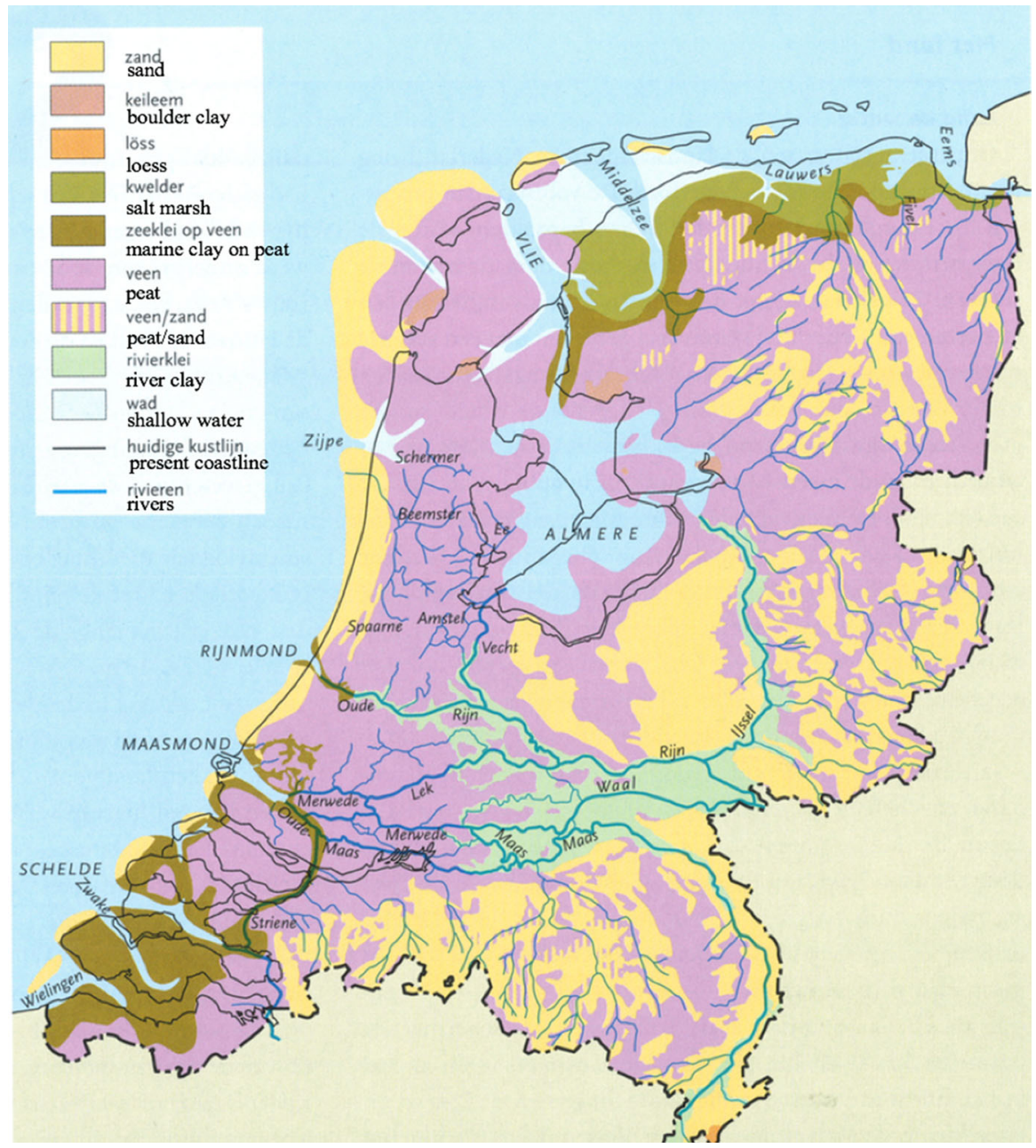

Fig. 1 Soil map of the Netherlands circa 800. At that time, there was still extensively developed peat land in the Netherlands (van de Ven 2003, p. 40)

the ground level to subside steadily. It has been suggested that large parts of Holland have sunk as much as four metres over the past thousand years. ${ }^{4}$ Besides that, peat was also dug as a cheap source of fuel for heating and industrial uses, which created many small ponds. As years went by, many of these ponds merged into larger lakes, the most famous being the extensive Haarlemmermeer, which stretched from Leiden as far as Haarlem and Amsterdam to the north. This lake emerged, partly as the result of storm surges, but mainly as the result of peat mining along the shores, thus rather man-induced than nature-induced. ${ }^{5}$ The Haarlemmermeer continued

\footnotetext{
${ }^{4}$ Henderikx (1988: p. 563).

5 van Dam (2001: pp. 32-45).
} 
expanding in the early modern period until it was finally drained and reclaimed between 1839 and 1852, with the help of steam-powered pumping stations. ${ }^{6}$ The subsidence and loss of peat land posed the most pressing threat to Holland in the sixteenth century, which was on course to becoming the economic centre of the Rhine River delta and even of the European world economy (Fig. 2).

South of the province of Holland, the island province of Zeeland ("sea land") was threatened by water as well, but less from the overflowing rivers than from the encroaching sea. During the Middle Ages, a large part of this territory was consumed by storm floods, which leapt over and destroyed the weak dikes. This natural situation worsened owing to human intervention during the Dutch Revolt (1568-1648), when Zeeland became the frontline between the insurgent Dutch Republic and the Spanish Habsburg regime. At the time, dikes were often intentionally destroyed to inundate a particular area in military actions, and hence large plots of land were lost to the sea (Fig. 3). ${ }^{7}$

The physiography of the Yangzi River delta is as diversified as the Rhine delta. According to Shiba Yoshinobu, there are six types of land in the Jiangnan region: "in order of elevation, (1) hills, (2) fan/slope complexes, (3) elevated plains, (4) low-lying plains, (5) sandy elevation, and (6) lowland". ${ }^{8}$ Shiba has mostly focused on the southern part of the Jiangnan region, which is not situated within the Yangzi River delta but along the Hangzhou Bay. For the plain adjacent to the Yangzi River, there are two types of land most relevant to this research, that are the sandy elevation and the lowland. In the recent research made by Xie Shi, these two subregions are labelled gaoxiang (高乡, higher area), which is made up of several ranges of sand dunes, and dixiang (低乡, lower area), which consists of low-lying polder areas. ${ }^{9}$ Besides that, what has yet to be studied by historians is the shazhou (沙洲, sand bars) areas in the estuary of the Yangzi River, which will be pointed out later in this article as the site of the most remarkable land reclamation in the early modern Yangzi River delta.

In the sixteenth-century Yangzi River delta, the dilemma of water management mainly concerned the connection between the gaoxiang and dixiang areas. The Jiangnan dune area, gaoxiang, was much larger in size than in Holland and impeded the outflow of surface water from the lower dixiang area. Therefore, although the lower embanked land (polder) area of Jiangnan was not subject to the oxidization and subsidence of peat as in Holland, it actually faced difficulty in draining its water. This situation worsened steadily in the sixteenth century, when people in the gaoxiang had become lukewarm about maintaining the irrigation system as they focused increasingly on cotton cultivation, which did not depend on irrigation. As a result, several important outlets through the dune area of Jiangnan silted up and the inner polder area could no longer find a reliable outlet for draining the superfluous water. ${ }^{10}$

\footnotetext{
6 Jeurgens (1991).

7 van Cruyningen (2006, 2014).

${ }^{8}$ Shiba (2011: pp. 232-233).

${ }^{9}$ Xie (2015).

${ }^{10}$ Ibid.
} 

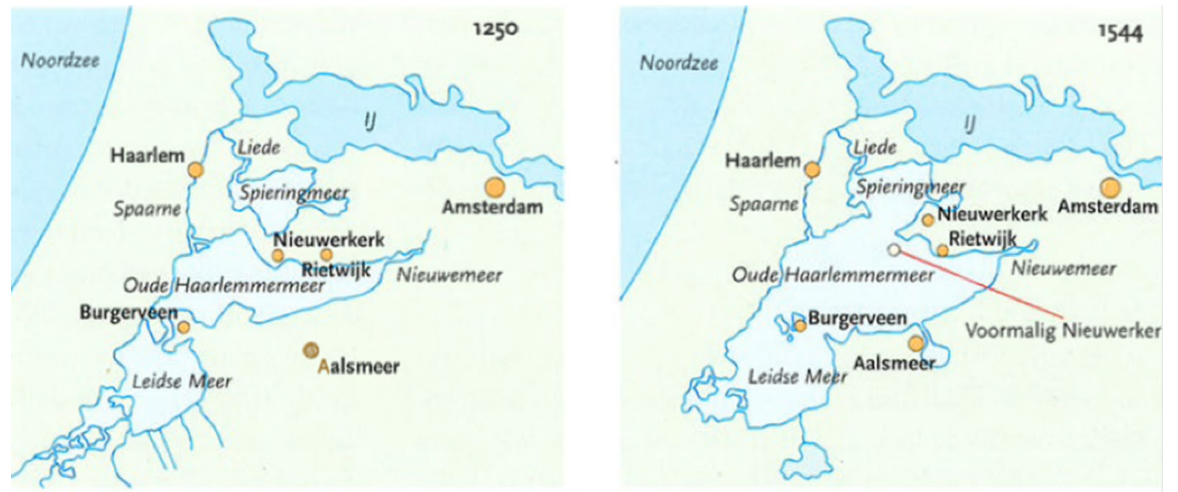

Fig. 2 The growth of the Haarlemmermeer between 1250 and 1544 (van de Ven 2004, p. 127)

Meanwhile, beyond the range of dunes, sandbars shifted position in the estuary of the Yangzi River. Sand islands emerged, moved, disappeared, and re-emerged. As a result, the counties of Chongming and Haimen had to move their county seats several times throughout the Ming period (1368-1644), and Haimen county was even dissolved in the mid-seventeenth century after most of its territory was lost to the sea. Up to the sixteenth century, these sandbars had little agricultural value and mainly served as salt pans, homes for fishermen, and pirates' lairs. ${ }^{11}$ However, during the mid-seventeenth-century Ming-Qing transition, some of the biggest sandy islands in this area were embanked and linked into larger entities by local people and military forces and thus became more or less stable islands. ${ }^{12}$ According to the contemporary sources of the United (Dutch) East India Company (VOC), during his assault of Nanjing in 1659, the Ming loyalist Zheng Chenggong even played with the idea of turning Chongming Island into the base of his maritime empire so that he could monopolize the profitable trade between Japan and Jiangnan. To achieve this goal, he even offered "the best island in Nanjing [province]" to Japanese soldiers in exchange for military support from the shogun of Tokugawa Japan. ${ }^{13}$ Only when his ambitious campaign went awry did he turn his eyes to Taiwan.

\section{The Paths Taken in the Netherlands}

Land reclamation in the early modern Netherlands took place in three sub-regions of the Rhine delta and beyond. In the province of North Holland, large-scale land reclamation occurred in the first half of the seventeenth century, which marked a new age of land reclamation by using improved windmills to pump out entire lake basins and develop them into polders (droogmakerij). In the province of South

\footnotetext{
$11 \mathrm{Wu}(2012)$.

12 KXCMXZ: juan 3: pp. 24-25; juan 4: p. 10; and juan 5: pp. 26-27.

13 Cheng (2012: pp. 249-357).
} 


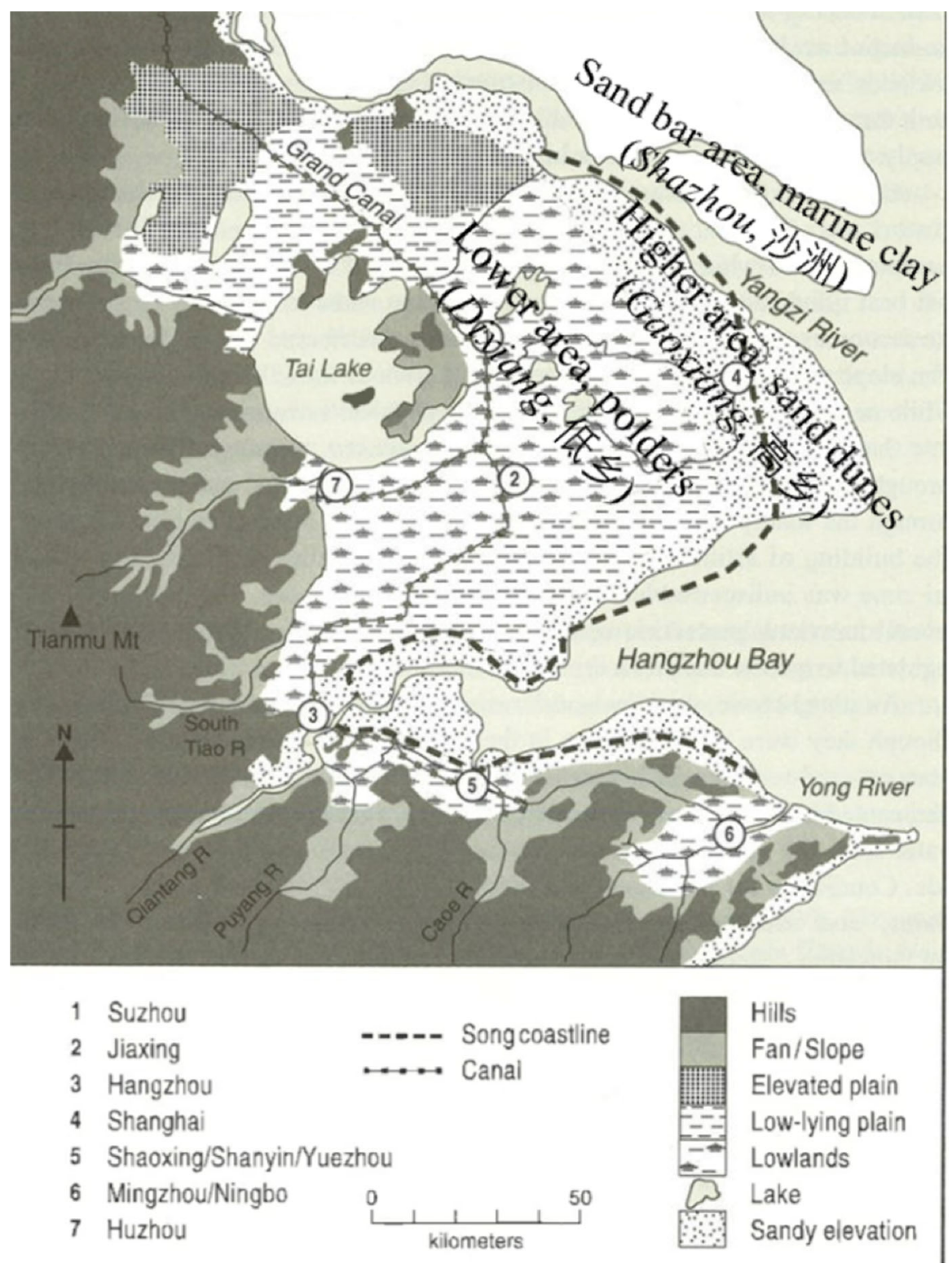

Fig. 3 Ecological zones of the Lower Yangzi delta with the division of dixiang (低乡), gaoxiang (高乡), and shazhou (沙洲). (Adopted from Shiba 2011, p. 234)

Holland, no significant land reclamation projects were carried out, but here regional water authorities were gradually centralized in a process called communalization (gemeenmaking) ${ }^{14}$ in order to improve the drainage of superfluous water from the

${ }_{14}$ See paragraphs 2.2 . 
gradually subsiding land to the sea and to throw up defence works against the expansion of the enormous inland lake, the Haarlemmermeer. In the estuary of the Rhine-Meuse-Scheldt Rivers (South Holland and Zeeland), large-scale land reclamation was also carried out by regional water authorities on submerged areas that had been lost to storm floods in the medieval period. This was undoubtedly an easier job to carry out than the droogmakerij in North Holland, since the sandbars were more or less level with the sea. In short: In the north lakes were drained (droogmakerijen) from about 1530 onwards, in the middle peat bogs were drained from about 1000, and in the south river isles were reclaimed, also from about 1000 (Figs. 4, 5).

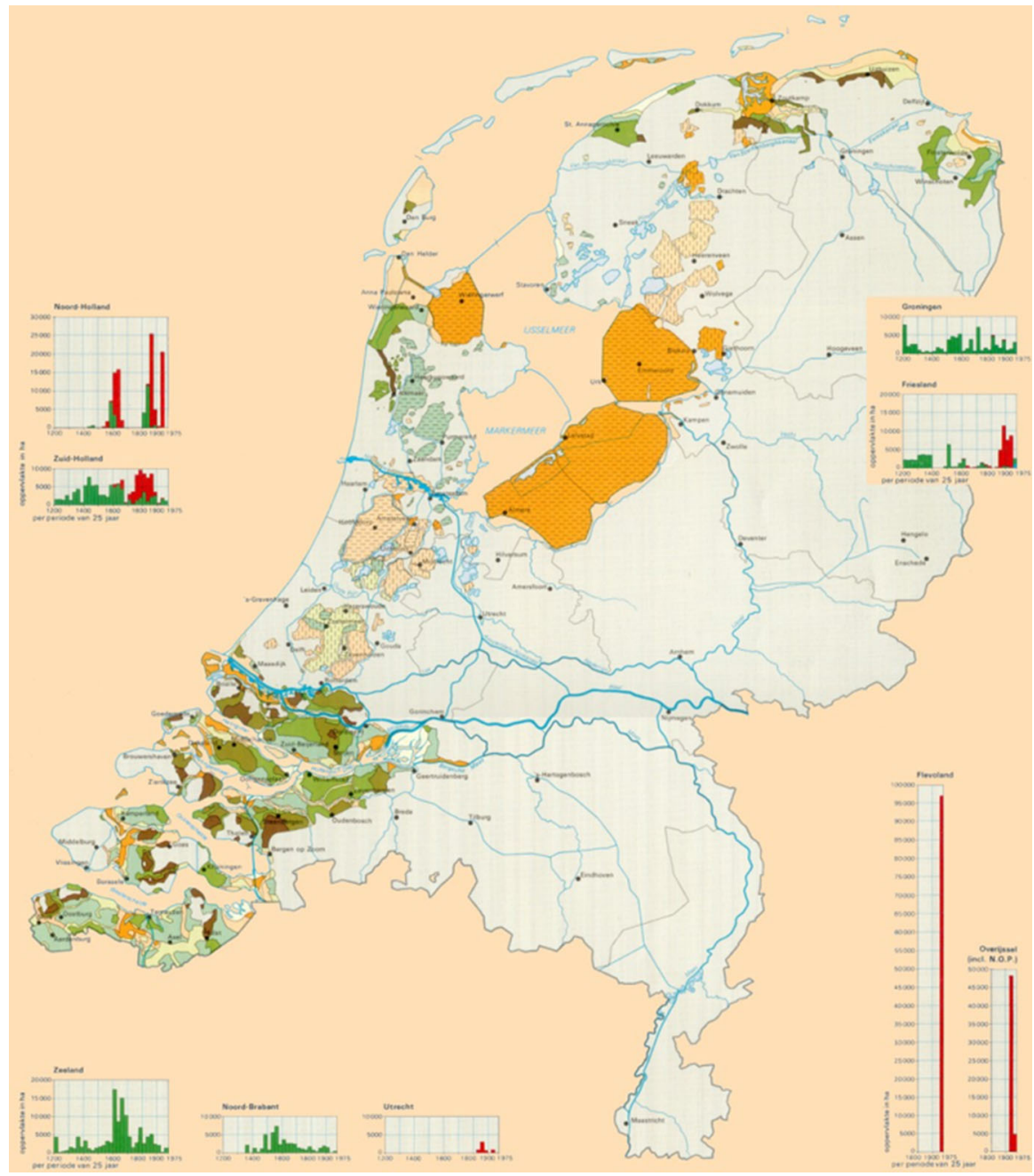

Fig. 4 Land reclamation since 1300_1 (Atlas van Nederland, vol. 15, Water (1988) (Stichting Wetenschappelijke Atlas van Nederland, 2001, http://avn.geo.uu.nl/index15.html, accessed 15 October 2017)) 


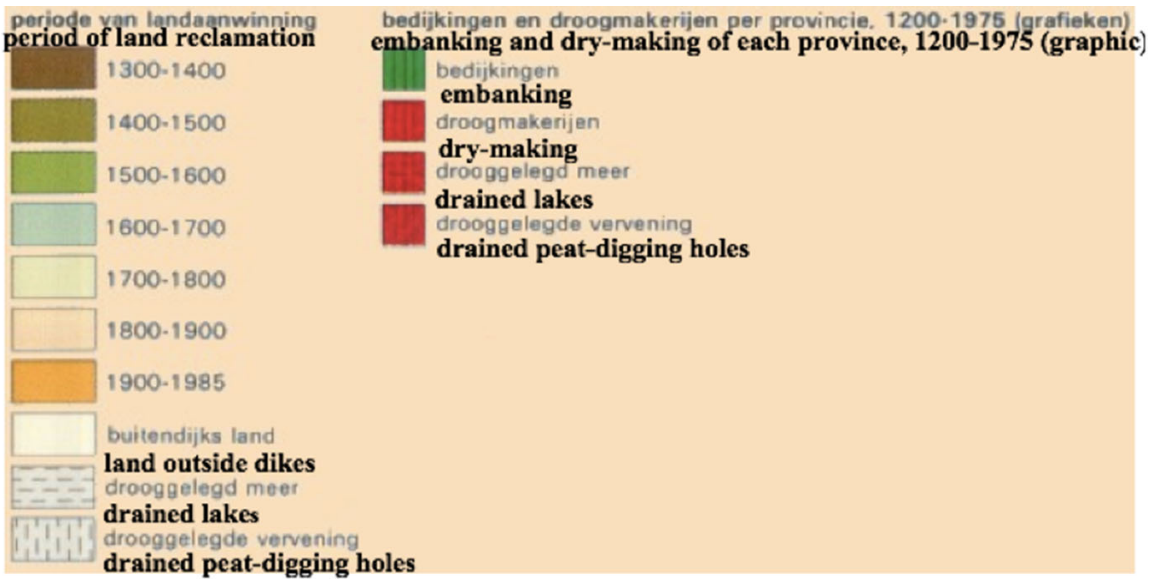

Fig. 5 Land reclamation since 1300_2 (Atlas van Nederland, vol. 15, Water (1988) (Stichting Wetenschappelijke Atlas van Nederland, 2001, http://avn.geo.uu.nl/index15.html, accessed 15 October 2017))

\subsection{Droogmakerij (Dry Making) in North Holland}

In North Holland, that is, the area north of Amsterdam, several lakes were formed during the medieval period thanks to the combined effects of soil subsidence and peat digging. In the sixteenth century, an engineer with the telling name of Leeghwater (literally, "empty water") invented a new technology to drain these lakes with the help of highly efficient windmills. ${ }^{15}$ These droogmakerij projects were mostly undertaken in the early seventeenth century, partly because of the thenhigh price of grain in the Netherlands, but also because of the invention of a new financial instrument: the joint stock company for raising funds and investment in land reclamation projects. The Beemster Polder (drained in 1612) was the biggest and best-known reclamation project in the province of North Holland. As van Cruyningen explains, the reclamation of the Beemster polder was due to institutional innovations (new procedures: the contentment clause and no right of appeal) which helped to reduce resistance of local villages and towns (damaged landownership, fishing rights and other interests). ${ }^{16}$ This was the institutional basis of all other lake reclamations. Wealthy merchants living in Amsterdam invested their capital in the reclamation of the Beemster lake with the help of Leeghwater's newly designed windmills. ${ }^{17}$ These were positioned on different levels of watering or drainage canals so that they could drain water from the deepest area of the polder step by step out to the rivers or to the Zuiderzee (today's IJsselmeer, which is cut off from the North Sea by a $32-\mathrm{km}$ dike). Before the windmills were installed and

\footnotetext{
15 Windmills used for drainage purposes were already functioning in the first half of the fifteenth century, see Henderikx (1988: p. 569).

16 van Cruyningen (2015: p. 427). For institutional procedures connected with the development of good water governance, see also van Tielhof (2017: pp. 431-453).

17 Fleischer (2007: p. 151).
} 
ditches were dug, surveyors, who were practicing triangulation techniques, were commissioned to produce a perfecte caerte (perfect map) of the lake. ${ }^{18}$ During the drainage, they continuously surveyed and made new maps. They measured the depth of the lake and also designed the best locations to set up mills and dig the discharge canals. These maps showed not only natural features and drawings of infrastructure, but also artificial boundaries of the new polder; the anticipated plots of the reclaimed land were also numbered. ${ }^{19}$ With the help of this cadastral map, the polder was partitioned among the shareholders in Amsterdam even before it came into existence (Fig. 6).

The investors behind the Beemster drainage had a clear idea of how to capitalize their assets and how to sell shares on the financial market by dividing huge assets into many stakes. This system was also practised at roughly the same time in the creation of the Dutch East India Company, chartered in 1602. It is no accident that the first investors in the Beemster included the wealthy merchant brothers, Dirck and Hendrik van Os, who were also cofounders of the VOC. ${ }^{20}$

The reclamation procedure of the Beemster was not unique. The same method was used to turn many more lakes into polders, including the Wieringerwaard (1597), Wogmeer (1608), Wormer (1624), and Schermer (1635). ${ }^{21}$ According to Jan de Vries and Ad van der Woude, in a short period from 1610 to 1640, "leading Amsterdam merchants and other urban interests dared to plunge at least ten million guilders-far more than they and their contemporaries had invested to establish the Dutch East India Company in 1602 - into the application of new windmill pumping techniques to the drainage of a series of lakes covering in total 26,000 hectare". ${ }^{22}$

It should be noted that this figure does not include the even greater swathes of land reclaimed in and around the south-west provinces, such as Zeeland, which will be discussed later in this paper. Regardless, we can imagine how much money was invested in reclaiming land that originally appeared on land maps as lakes, just as capital had been raised for the overseas trading companies whose activities and privileges were initially only visible on maritime maps (Fig. 7). ${ }^{23}$

\subsection{Communalization (gemeenmaking) in South Holland}

South of Amsterdam, land reclamation was hindered by the expansion of a large inland lake, the Haarlemmermeer. The whole land area from Amsterdam to Rotterdam was divided into three big drainage systems: Rijnland, Delfland, and Schieland. Rijnland drained its superfluous water into the Haarlemmermeer reservoir and from there into the Zuiderzee, while Delfland and Schieland drained water directly to the Rhine estuary. These hydraulic systems were maintained by many small water boards that oversaw their own dikes and the drainage of water

\footnotetext{
18 Idem, p. 154.

19 Idem, pp. 152-154; Wieringa (1994); this article, Fig. 7.

${ }^{20}$ Fleischer (2007: pp. 151-152).

21 de Vries and van der Woude (1997: p. 28).

22 Idem, p. 29.

23 This connection has been previously discussed in Xu (2017: pp. 16-27).
} 


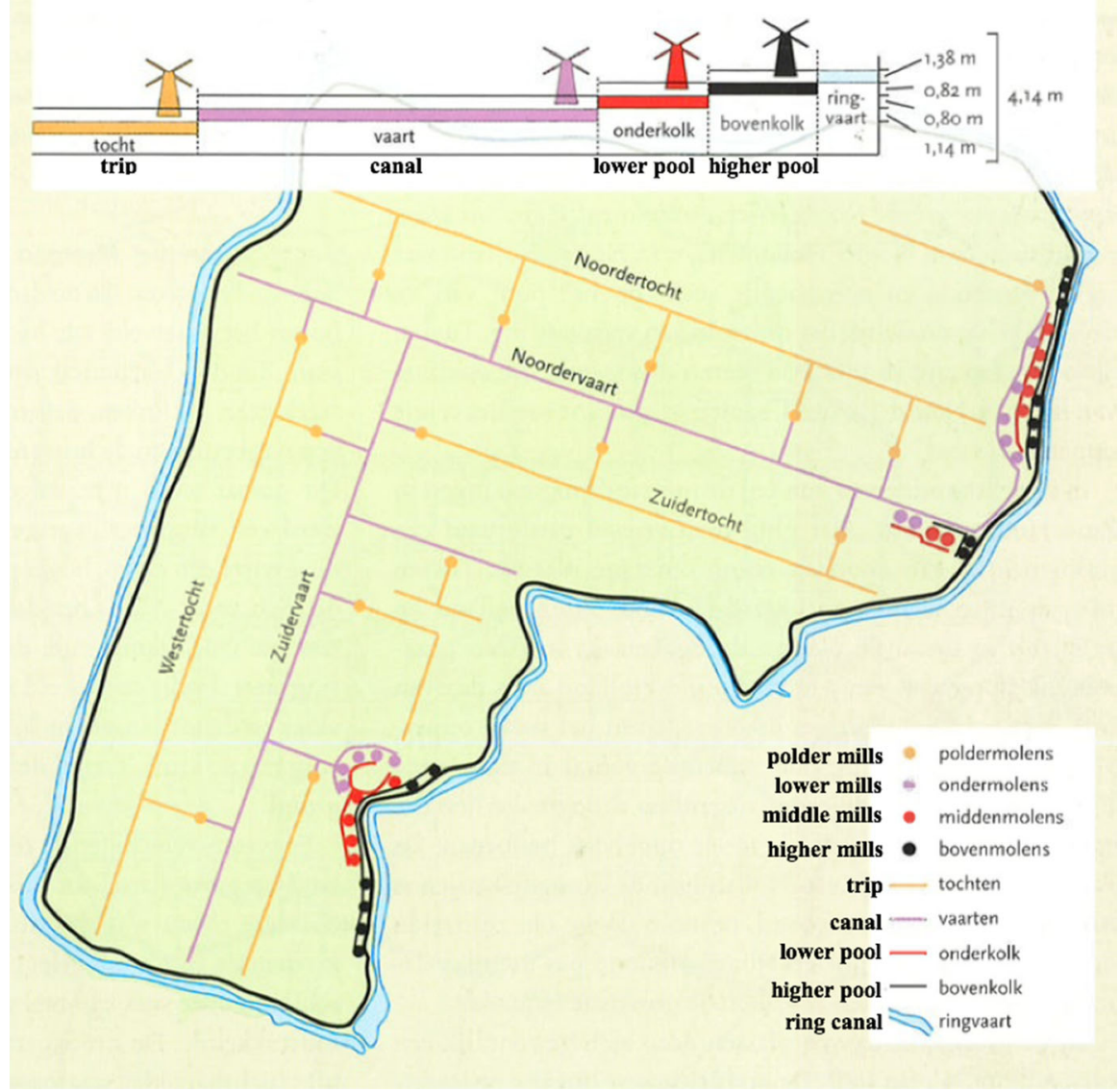

Fig. 6 The four-step dry making of Schermer in 1635 (van de Ven 2003, p. 161)

from their polders. Since the thirteenth century, these small water boards had been subordinate to three regional water boards under the authority of the Count of Holland and formed to coordinate small-scale operations as part of larger drainage systems.

The earliest and most important of these umbrella organizations was the Hoogheemraadschap van Rijnland (Rijnland Regional Water Authority). Before the sixteenth century, this organization mainly served as a regional court specializing in judging water management disputes. In the sixteenth century, as the Haarlemmermeer eventually formed by combining several previous smaller lakes, the local small water boards agreed to hand over more power to the Hoogheemraadschap. It began to have administrative functions and focused on the containment of the Haarlemmermeer and controlled its drainage points to the sea. ${ }^{24}$ Meanwhile, the local water boards were also changing. The farmers and peasants of the polder took

\footnotetext{
24 Tielhof and van Dam (2006a).
} 


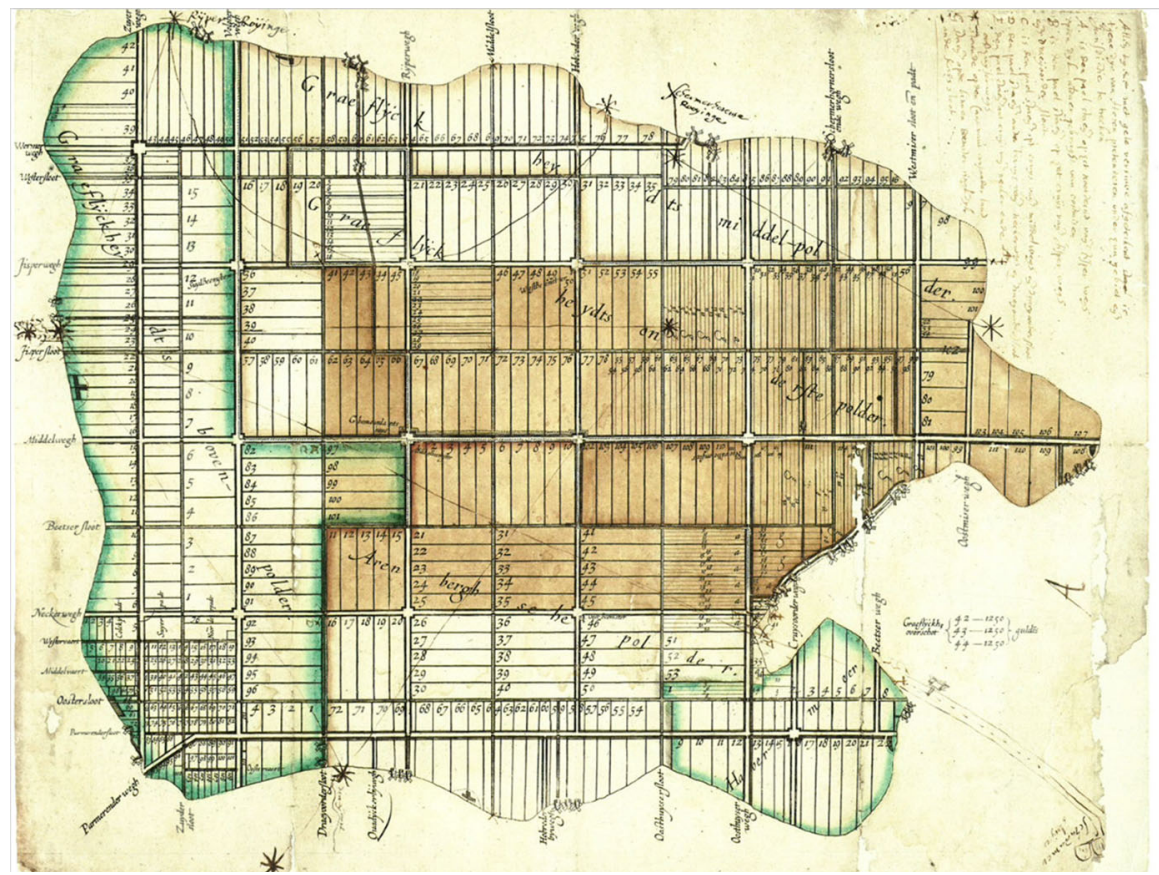

Fig. 7 Parcellation map for the Beemster, 1612 (Westfries Archive, Atl. bergnr. 1 G31, quoted by Steenbergen et al. 2009, p. 348)

the decision to introduce windmills to drain water from their polders, which had subsided so far below the sea level that the excess water could no longer be emptied into the rivers via sluices. All landowners and land users participated in the governance of water at the local level of the polder. ${ }^{25}$ By tradition, every landowner was responsible for a part of the embankment of his polder, according to the amount of land he owned, the so-called verhoefslaging. In place of this antiquated system, the water boards began to charge the landowners fixed amounts of money and employed specialized labour to maintain the dikes and to drain the water from the polder. ${ }^{26}$ Along with this so-called communalization process, all polders were measured by professionally trained and licensed land surveyors who used the most up-to-date survey instruments, such as the Holland circle (similar to a theodolite), and applied advanced survey techniques such as triangulation. Local water boards could rely on the cadastral maps as the basis of water management and tax collection. ${ }^{27}$

To serve the needs of these polder boards, in 1600, Leiden University, which normally taught all courses in Latin, opened an engineering school where the

\footnotetext{
25 Brusse (2017).

26 Zeischka (2006).

27 Tielhof and van Dam (2006a: pp. 82-86), and Pouls (1997: pp. 145-151, 274-276, 2004).
} 
famous scientist and mathematician Simon Stevin specifically taught mathematics to surveyors in the Dutch language (Duytsche mathematicque). The surveyors trained there played a big role in the water management of the Netherlands. ${ }^{28}$ The institutional training in technology, civil engineering, and other forms of "useful knowledge" produced a high level of prosperity in the early modern Netherlands and has been aptly coined the "age of the industrious revolution". ${ }^{29}$ Because of the windmill revolution, the mechanization of the production processes could be applied on a much larger scale. Windmills were used for all kinds of industrial applications. The great prosperity thus provided ironically accounts for the relatively late transition from wind to steam power in the Netherlands in the nineteenth century. ${ }^{30}$ Similarly, as developed ancient hydraulics may have been, the solution of real fundamental theoretical questions such as the calculation of the speed of water in a scientific manner by the Jesuit cleric Benedetto Castelli in his Della misura delle'acque correnti, a study published in 1628, had to wait for the onset of the scientific revolution of the later seventeenth century before it could be applied in practice. The historical development of water control as a network of knowledge and know-how in which various traditions of hydraulics came to interact with each other is a perfect example of globalization. ${ }^{31}$ In his study Religion, Technology, and the Great and Little Divergences Karel Davids offers a new perspective on technological change in China and Europe before the Industrial Revolution. This book makes an innovative contribution to current debates on the origins of the "Great Divergence" between China and Europe and the "Little Divergence" within Europe by analysing the relationship between the evolution of technical knowledge and religious contexts. It takes a comparative look at the relation between technology and religion in China and Europe between c.700 and 1800 from four angles: visions on the uses of nature, the formation of human capital, the circulation of technical knowledge, and technical innovation (Fig. 8). ${ }^{32}$

\subsection{Massive Reclamation in the Estuary of the South-western Provinces}

The estuary area in the south-western Low Countries, consisting of the islands of South Holland, the western part of the province of Brabant, and all of the province of Zeeland, has received less scholarly attention than the peat lands of North and South Holland. Yet it was here that the largest land reclamation projects in the Rhine River delta were carried out in the early modern period. Whereas 26,000 hectares of land were reclaimed by draining lakes in North Holland, some 103,000 hectares of submerged area were embanked and reclaimed from the sea in the estuaries of the south-west Netherlands. ${ }^{33}$ Different from the droogmakerij in North

\footnotetext{
28 Pouls (1997: pp. 156-157, 168).

29 On the "industrious revolution" see: Vries (2008). For a broad survey of early modern Dutch technology see: Davids (2008: vol. 1, pp. 60-88).

30 Kaptein (2017).

31 See the stimulating article by Ciriacono (2008: pp. 239-256).

32 Davids (2012). Many thanks to Petra van Dam for pointing out this important study.

33 van Cruyningen (2006).
} 


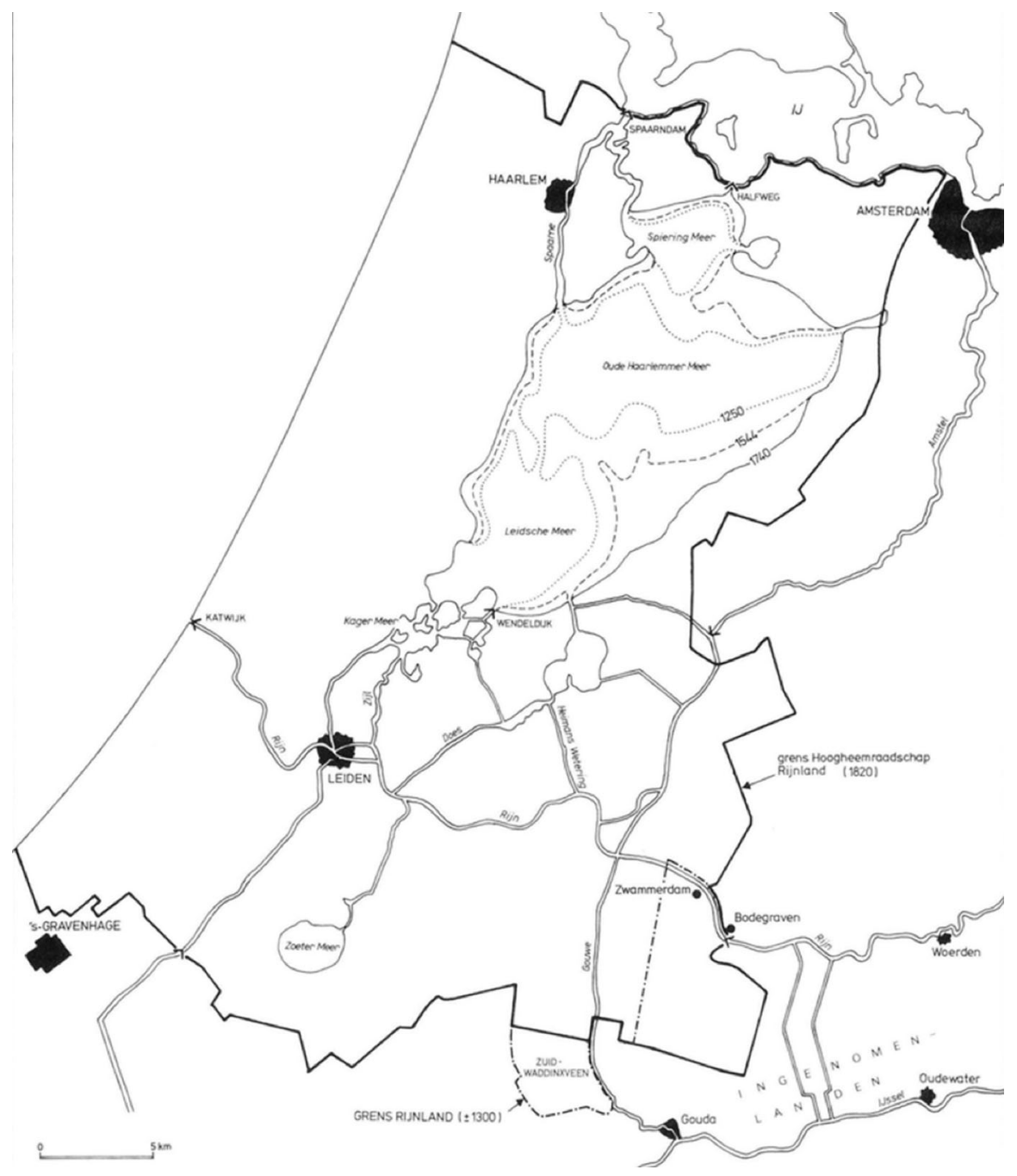

Fig. 8 Map showing Rijnland in 1820 (Giebels 1988, p. 11) and (Zeischka 2006)

Holland, the success in the south-western area did not rely so much on technological renovation as on financial institutions and environmental advantage. ${ }^{34}$ It should be added that much of the reclaimed land was originally part of a much larger area of land that had been lost to large floods in medieval times (Fig. 9).

The reason for its previous submergence is linked to the nature of peat land. As in South and North Holland, the submerged lands of the south-west Netherlands had once been peat land. This had subsided after it was drained in the medieval period, and due to its direct exposure to the sea, it was more easily eroded by dike-breaking storm floods. Therefore, from the thirteenth to early fifteenth centuries, a large part

\footnotetext{
34 van Cruyningen (2014) and van Tielhof (2015).
} 


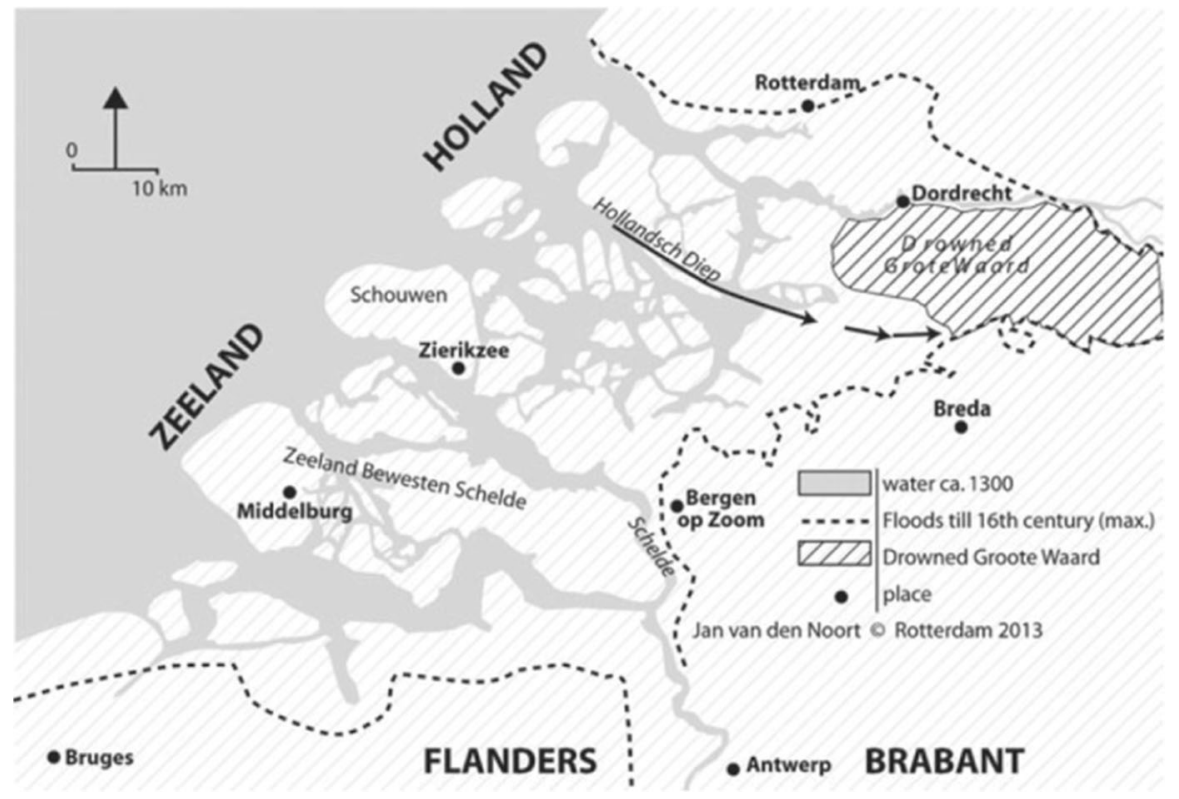

Fig. 9 Flooded areas in the south-western Netherlands, fifteenth and sixteenth centuries. (Map by Jan van den Noort, in van Cruyningen 2014, pp. 241-265)

of this area was lost to the sea, and the medieval water management system simply collapsed.

Ironically, the advantage of this collapse was that the remaining peat on the top of the land was washed away by the intruding sea waves and partly replaced by new and fertile marine clay that, owing to the process of siltation, gradually became higher than the sea level. All these changes prepared advantageous conditions for the new wave of capitalist land reclamation in the early seventeenth century, the socalled Dutch Golden Age. ${ }^{35}$

After the initial years of the Dutch Revolt, the Dutch Republic gradually consolidated its territorial control in the estuary, and at the same time, the merchant and urban class in Zeeland gradually changed their portfolio of investments by leaning more towards commercial agriculture. That trend became especially apparent in the province of Zeeland during the Twelve Years' Truce (1609-21), when the profitable privateering against the Spanish enemy was no longer allowed, and shipping and trading businesses moved increasingly towards Amsterdam. The Zeeland merchants who had previously accumulated substantial capital through privateering, trading with the Caribbean, and investing in the Dutch East India Company, began to organize new companies for land reclamation. ${ }^{36}$

The organization of land reclamation companies resembled somewhat that of the East India Company, although the shareholders were not allowed to freely transfer

\footnotetext{
35 Ibid.

36 Ibid. and van Tielhof (2015).
} 
their shares without permission from other shareholders. Before setting out on their venture, they first of all needed to obtain an octrooi (a charter, or exclusive right) from the provincial government or the national government (the States General). The government took advice from specialized commissioners about the technical feasibility and ecological consequences of the project and often sent them to investigate the area. After obtaining the octrooi, the investors could set up a drainage consortium to reclaim the land. They had to pay compensation to the previous owners, who might still press their rights to the submerged land. They would also receive a certain period of tax exemption from the state. After the land was reclaimed, every urban investor would obtain a fixed proportion of the new land. He could either transfer it to others immediately, or lease it out to tenants. These tenants were not necessary poor peasants; many were agricultural entrepreneurs who rented adjacent land from different owners and linked them together to establish large farms for commercial agriculture. In Zeeland, the land they reclaimed was usually above sea level and hence windmills were not necessary. The water boards for these polders only needed to build outlets for draining the excess water and had to maintain the sea dikes to protect against tides and storm surges. The fertility of the marine clay was well preserved by the landowners and tenants, and the major crops were wheat for food and madder for dying purposes. This differed significantly from the case in North Holland, where due to the low land level, the land was too wet for cereal cultivation even after constant drainage by windmills. The major use of the land reclaimed in North Holland was meadowland for breeding cows, which produced dairy products and beef. $^{37}$

\subsection{The Emergence of the Shipworm Plague and the Reconstruction of Sea Dikes in the Eighteenth Century}

Unlike in Jiangnan, the sand dunes of the lower Rhine river were much weaker and in the medieval period the sea had broken through major parts of them-the process through which the Zuiderzee (South Sea) was created-and invaded deep into the peat land and estuary areas. To defend against the encroaching sea water, there had been sea dikes since the medieval period, most of them built of peat and clay. At critical sections, they were protected by wooden pile screens on the seaward side or cushions of dried seaweed buttressed by wooden piles that functioned as palisades. Figure 10 shows the cushions type of construction. ${ }^{38}$

However, due to changes in the marine environment, such as increased salinity, and the intensified maritime exchange with tropical waters of the West and East Indies, a previously unknown species of shipworm, the Teredo navalis, began to massively infest the wood piles in 1730 . This put the sea defence system in grave danger, since the worms bored into the piles and caused them to be broken by the sea waves within a short period. Without these wooden piles, the dried seaweed was

\footnotetext{
${ }^{37}$ Ibid.

${ }^{38}$ Sundberg (2015: pp. 170-174).
} 


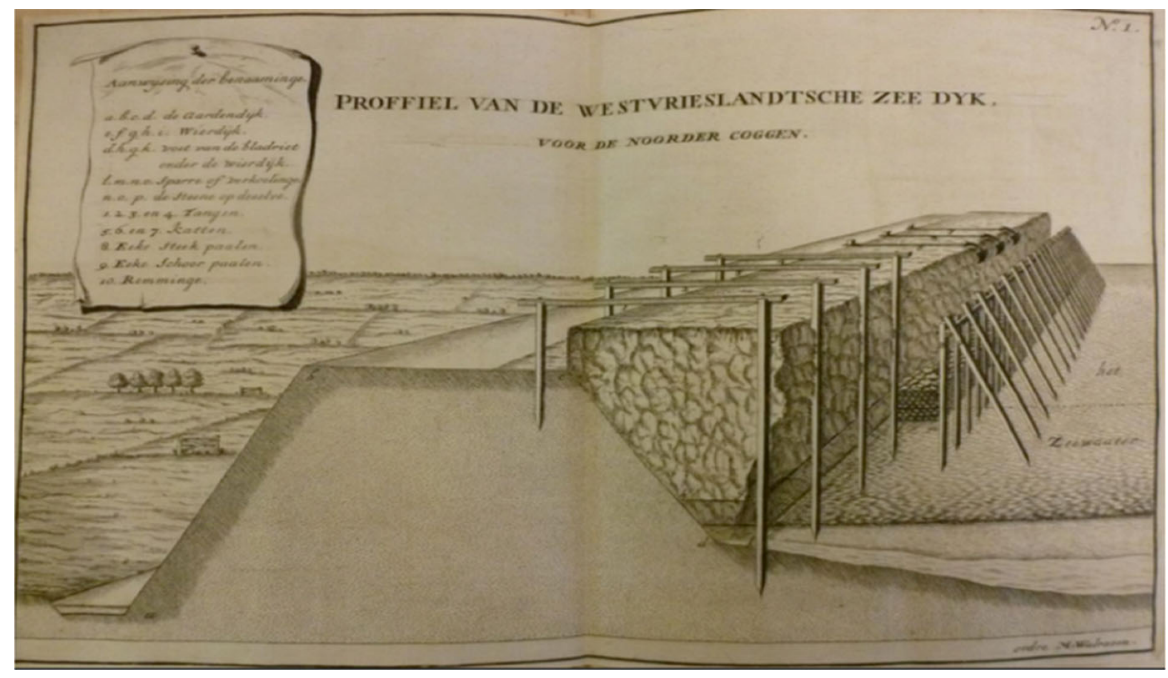

Fig. 10 "Profile of the West Frisian Sea Dike" (from Nationaal Archief, The Hague, Toe. 3.01.05, Inv. 3932, p. 94, quoted by Sundberg 2015, p. 172)

washed away and the earthen sea dikes faced direct erosion by the tides and the breakers dashing against the coast. ${ }^{39}$

Initially, regional water boards and provincial governments sought to solve this crisis through traditional and economic ways, but as the foreign media began to exaggerate the crisis, which threatened the public's confidence in the future of Amsterdam as the economic centre of Europe, alternative techniques of coastal protection were needed. The Dutch government was forced to adopt a novel, allencompassing, and expensive solution that replaced the wood piles with stone facing material. Provincial administrations were obliged to subsidize these projects, since the expense needed for their execution far exceeded the financial capacity of the regional water boards (Fig. 11). ${ }^{40}$

\subsection{Consequences and Connections with the Dutch Economy}

By the middle of the seventeenth century, the Dutch economy had become so urbanized and so connected to the emerging world economy that commercial agriculture was no longer the main pillar of the domestic economy. This point is also reflected in the use of the newly reclaimed land from the lakes in North Holland. If these new lands were said to have been originally designed to produce grain to supply the growing demand in the cities-about half of the Dutch population lived in towns-it soon turned out that the soil of the lakes-in contrast to the reclaimed clay soil in the south-western estuaries-was rather poor. Moreover, the Dutch grain crops could no longer compete with the cheap grain

\footnotetext{
39 Idem, pp. 159-169.

40 Idem, pp. 170-202; Koopmans (2016: pp. 139-50); and de Vries and van der Woude (1997: p. 123).
} 


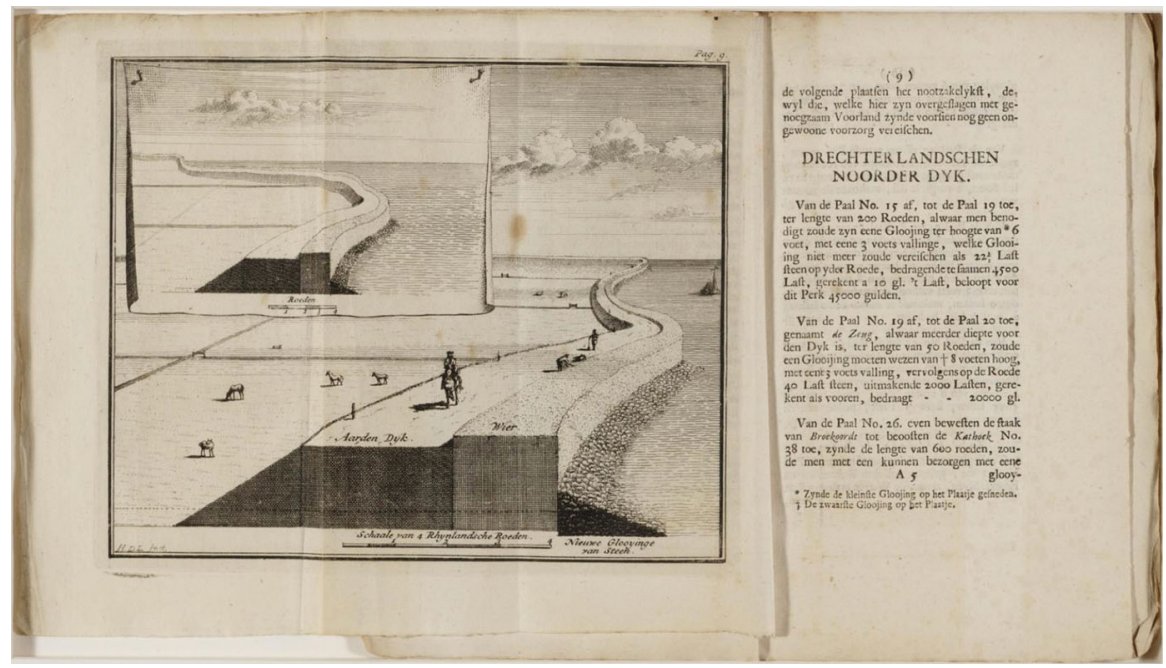

Fig. 11 The restructured sea dike. The wood piles on the seaward side were replaced by a stone slope (quoted by Sundberg 2015, p. 195)

imported from the Baltic. Hence, farmland was turned into meadows for pastoral purposes such as cattle raising for the production of dairy and beef. An additional gain of this change in the mode of production was that the pasture land could remain wetter than the land used for agriculture so that the soil was less subject to subsidence.

Land reclamation in the estuary area of the less urbanized south-western province of Zeeland was more successful for agricultural purposes because it helped that area turn away from an economy uniquely dependent on fishing, maritime trade, and privateering. Its major products, wheat and madder, provided food and dying material to the urban centres in the Netherlands. ${ }^{41}$

\section{The Paths Taken in Jiangnan}

There were three stages of land reclamation in early modern Jiangnan as well, but massive land reclamation only happened in one place. Like Holland, the lower area, the so-called dixiang (低乡), of Jiangnan contained many large freshwater lakes, among which the most important is Taihu (太湖, Lake Tai). Before the sixteenth century, the major land reclamation and improvements took place in the polders in this lower area. However, in the sixteenth century, land reclamation slowed down there and many existing polders were divided into smaller units for easy water management and taxation. Henceforth, the central stage of large-scale hydraulic reclamation projects moved to the sand bars (沙洲) in the estuary of the Yangzi River, around the present island of Chongming (崇明), and the north shore of the Yangzi River, Haimen (海门). Besides that, along the coastal plain of the sand dune

41 van Cruyningen (2014). 
area, that is, the so-called gaoxiang, the Qing imperial state managed to coordinate a series of large-scale sea-dike-building projects in the eighteenth century, which helped stabilize the coastline of Jiangnan and also became the baseline for the further reclamation of tidelands into the nineteenth century.

\subsection{Dividing Polders in the dixiang (低乡, Lower Area)}

Jiangnan had a long tradition of building polders, but, as in Holland, the major projects took place between the tenth and thirteenth centuries, that is, from the Wuyue dynasty (吴越) to the Song dynasty. ${ }^{42}$ At that time, the government organized the construction of several important dikes in Jiangnan, which helped local communities drain water from the swamps. ${ }^{43}$ Along these dikes, many largescale polders were built. Into the early Ming period, the so-called lijia (里甲) system was applied to the existing polders. ${ }^{44}$ Briefly explained, this community selfmonitoring system represented the administration of taxes and services below the county (xian, 县) level. Ideally ali headed by a headman or lizhang (里长) included 110 households. These 110 households were further subdivided into $10 \mathrm{jia}$, among which 10 families were selected as heads of each jia, that is, jiazhang (甲长).

The maintenance of water system took place under the supervision of liangzhang (粮长, grain chiefs), who were in charge of the collection and delivery of grain as tax to the state, and the lizhang, who operated under the liangzhang in collecting taxes. Shortly thereafter, in the fifteenth century, the local government also appointed tangzhang (塘长, dike chiefs) who specialized in polder maintenance. ${ }^{45}$

However, mainly owing to the rise of absenteeism, these systems failed to function well by the middle of the sixteenth century. Initially, a large number of entrepreneurial landowners remained residing in the rural society. They made up of the majority of the so-called liangzhang, lizhang, tangzhang, and weizhang, and they led local society in such communal tasks as polder maintenance and tax collection. ${ }^{46}$ However, from the sixteenth century onwards, there emerged many market towns in Jiangnan. ${ }^{47}$ Hence, many landowners moved out to these market towns or transferred their landownership to gentry in the towns who were entitled to enjoy legal exemption from taxes and the cost of polder maintenance. ${ }^{48}$ As a result, those who remained in rural society were mainly tenants and small landowners. They were obliged to shoulder a heavier burden of polder maintenance because large stretches of land were now controlled by landowners who had legal exemption from the cost of polder maintenance. The peasants left behind were simply unable to organize themselves sufficiently to maintain the existing polder system. ${ }^{49}$

\footnotetext{
42 Liao (1985). Many thanks to Zhao Siyuan for recommending this book.

43 Xie (2010).

44 Hamashima (1982: pp. 9-65).

45 Ibid.

46 Idem, pp. 67-90; Hamashima (1980: pp. 69-76, 1989: pp. 101-22).

47 Wu (2006: pp. 51-71), and Fan (2005).

48 Hamashima (1980: pp. 76-82, 1982: pp. 67-129).

49 Hamashima (1982: pp. 67-129).
} 
At times, there were reforms proposed by local officials to reorganize the water management system. A renowned reformer was Geng Ju (耿桔). He was the magistrate of Changshu county at the beginning of the seventeenth century. Facing the mounting crisis in water management, which had led to difficulties in land tax collecting, Geng Ju designed a reform to overhaul the entire system. It drained the silted water ways, restored the damaged dykes of existing polders, and even regulated the maintenance of the water system within each polder. ${ }^{50}$ In association with that, Geng Ju compiled one of the most important water management books in Chinese history, Changshu Xian Shuili Quanshu (常熟县水利全书), which literally means the complete guidance of the water management in Changshu county. That book explains in great detail of how to build dikes according to different circumstances and how to share the cost of water management. ${ }^{51}$ However, although that reform brought great honour to Geng $\mathrm{Ju}$, it could not be duplicated and sustained institutionally. There was neither an education system like the universities in the Netherlands to spread that knowledge, nor organizations like the heemraden and hoogheemraadschap to apply that knowledge in sustainable practice. That book was only preserved in the form of manuscript. The success of Geng Ju in Changshu was not copied by other places, and even the water management of Changshu per se quickly deteriorated within a short period after that reform. ${ }^{52}$

To make matters worse, the rise of cotton cultivation in the gaoxiang, which was the dune areas situated between the polder area and the sea, led to neglect and even ignorance of waterway maintenance there. This is because the cultivation of cotton did not require a lot of irrigation. Hence, the local people were no longer interested in periodically dredging the waterways and even began to reclaim land on the silted waterways to cultivate cotton. All these developments brought about a situation in which the excess water from the polder area could no longer flow out easily via the dune areas into the sea and hence caused widespread inundation in the poorly maintained polder areas. ${ }^{53}$

Solutions were sought in two ways. First, the local government began to encourage peasants to divide the previously large-scale polders into smaller ones so that it was easier for them, who were mainly tenants, to look after the maintenance without the leadership of large landowners. ${ }^{54}$ At the same time, the government began to cancel the exemptions allowed to the gentry, who were now forced to pay the cost of water system maintenance according to the size of their land. This new system was called yeshidianli (业食佃力, “the landowners offer provisions, and the tenants offer labour"). ${ }^{55}$ In addition, the government also intervened in the conflicts between the people of the polder and dune areas and focused on the maintenance of several main rivers such as the Liu River (汶河), the Wusong River (吴淞江), and

\footnotetext{
50 Zhang (1985) and Wang (2011). Many thanks to Zhao Siyuan for pointing out the significance of this reform.

51 Ibid.

52 Ibid.

53 Xie (2012b: pp. 109-119, 2015: pp. 160-166).

54 Hamashima (1980: pp. 81-82, 1982: pp. 106-111) and Xie (2012a: pp. 349-354).

55 Hamashima (1980: pp. 82-88, 1982: pp. 131-181) and Xie (2012b: pp. 109-119, 2015: pp. 152-178).
} 
the Huangpu River (黄浦江) to ease the drainage of water from the polder area of Jiangnan to the sea. ${ }^{56}$

The results of these changes are reflected in Fei Hsiao-Tung's survey of the Kaihsienkung (Kaixiangong, 开弦弓) in the 1930s. This village was in the southern part of the lower area in Jiangnan. With a population of 1458, it was a relatively large village for Jiangnan. It had $3065.8 \mathrm{mu}$ (204 ha) of land, most of which was registered under absentee landlords. ${ }^{57}$ Its land consisted of eleven polders, of which the biggest was $986.4 \mathrm{mu}$ (66 ha), the smallest was $8.55 \mathrm{mu}(0.57 \mathrm{ha})$, and the majority were about one hundred or two hundred $\mathrm{mu},{ }^{58}$ that is, the average size of the polders divided in the sixteenth century. ${ }^{59}$ Yet this was much smaller than the size of the polders of the Netherlands. For instance, the largest polder of Kaihsienkung (66 ha) was tiny in comparison with the size of the 7200 ha Beemster polder in North Holland, which had been drained in 1612, and also much smaller than the Vierambachtspolder (1170 ha) in South Holland, which was created by combining several smaller polders in the early seventeenth century. It is also worth noting that in Kaihsienkung, the only way to pump out over-abundant water from these polders was to use foot-pedal watermills (脚踏翻车). The drainage work was carried out by the villagers themselves without the supervision of a higher regional water board (Figs. 12, 13). ${ }^{60}$

Hence, a new balance was achieved in the seventeenth-century polder areas. Now, the polders were divided into smaller units. The distribution of the expenditure of polder maintenance was no longer subject to the lijia system, but was based on landownership. Although most landowners now resided in the towns, they were still obliged to share the cost of water system maintenance in the rural area. The government no longer directly intervened in local polder maintenance, but focused on the maintenance of major rivers, which were essential for the drainage of water from the polder areas into the sea through the higher dunes.

\subsection{Massive Polder Building on the Sandbars (shazhou, 沙洲) in the Yangzi River Estuary}

While there had been barely any large-scale land reclamation in the lower areas of Jiangnan since the sixteenth century, the most important land reclamation in the early modern lower Yangzi River delta actually took place along the sandbars in the estuary of the Yangzi.

Different from the lower Rhine, the estuary of the lower Yangzi had a tremendous ecological advantage in land reclamation, that is, the supply of huge quantities of silt from the upper reaches of the river and, from the twelfth century onwards, from the Yellow River. After the shift of its mouth from north of the Shandong Peninsula to the south, the Yellow River began to supply sediment to the

\footnotetext{
56 Xie (2015: pp. 152-178).

57 Fei (1939: pp. 181-191).

58 Idem, pp. 7-26.

59 Hamashima (1982: pp. 106-111).

60 Idem, pp. 169-173.
} 


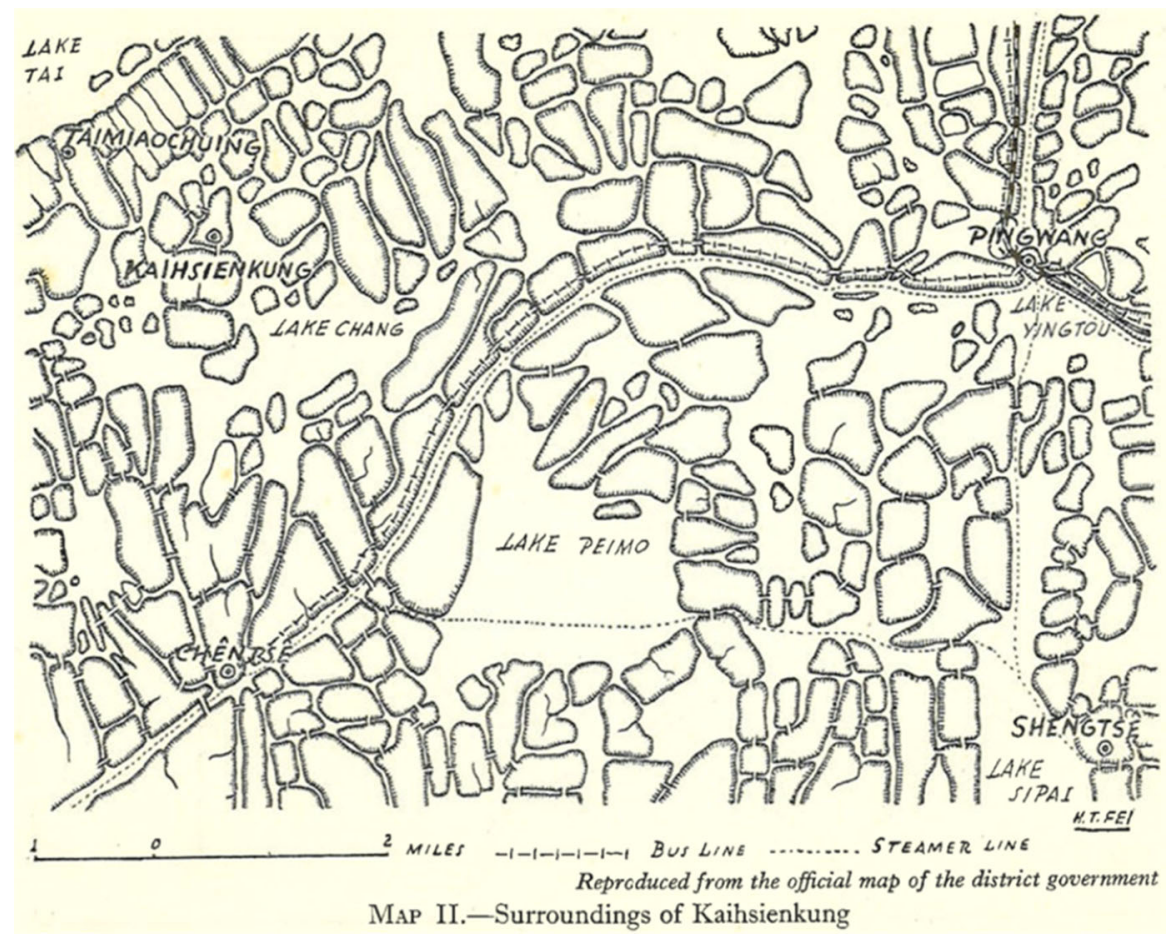

Fig. 12 The map around Kaihsienkung (开弦弓) village in the early twentieth century. It depicted a typical scene of the lower area of Jiangnan, with many small polders in intricate waterways (Fei 1939, p. 14)

Yellow Sea since the twelfth century and that marine sediment was pushed by ocean currents to the mouth of the Yangzi. The sediment from these two huge rivers contributed to the emergence of large sandbars in the Yangzi estuary. Yet these sandbars were unstable and could appear and disappear quite suddenly. Therefore, before the sixteenth century, sustainable land reclamation was hardly possible on these sandbars. The two counties, Chongming (崇明) and Haimen (海门), which administered these sandbars, did not even have stable county seats, as their land often collapsed into the sea by erosion. In the end, Haimen county lost most of its territory to the sea and was obliged to be dissolved in the seventeenth century, while Chongming county moved its county seat five times from 1352 to 1583 due to soil erosion. $^{61}$

However, since the late sixteenth century, communities in Chongming county began to systematically reclaim sandbars and introduce sustainable agriculture on these recently reclaimed lands. Consequently, after 1583 there was no longer any reason to move the county seat of Chongming. At the same time, many disputes emerged among local communities about the landownership of the newly reclaimed sandbars. These disputes lasted well into the Qing period. This unhappy situation

$61 \mathrm{Wu}$ (2012: p. 107). 


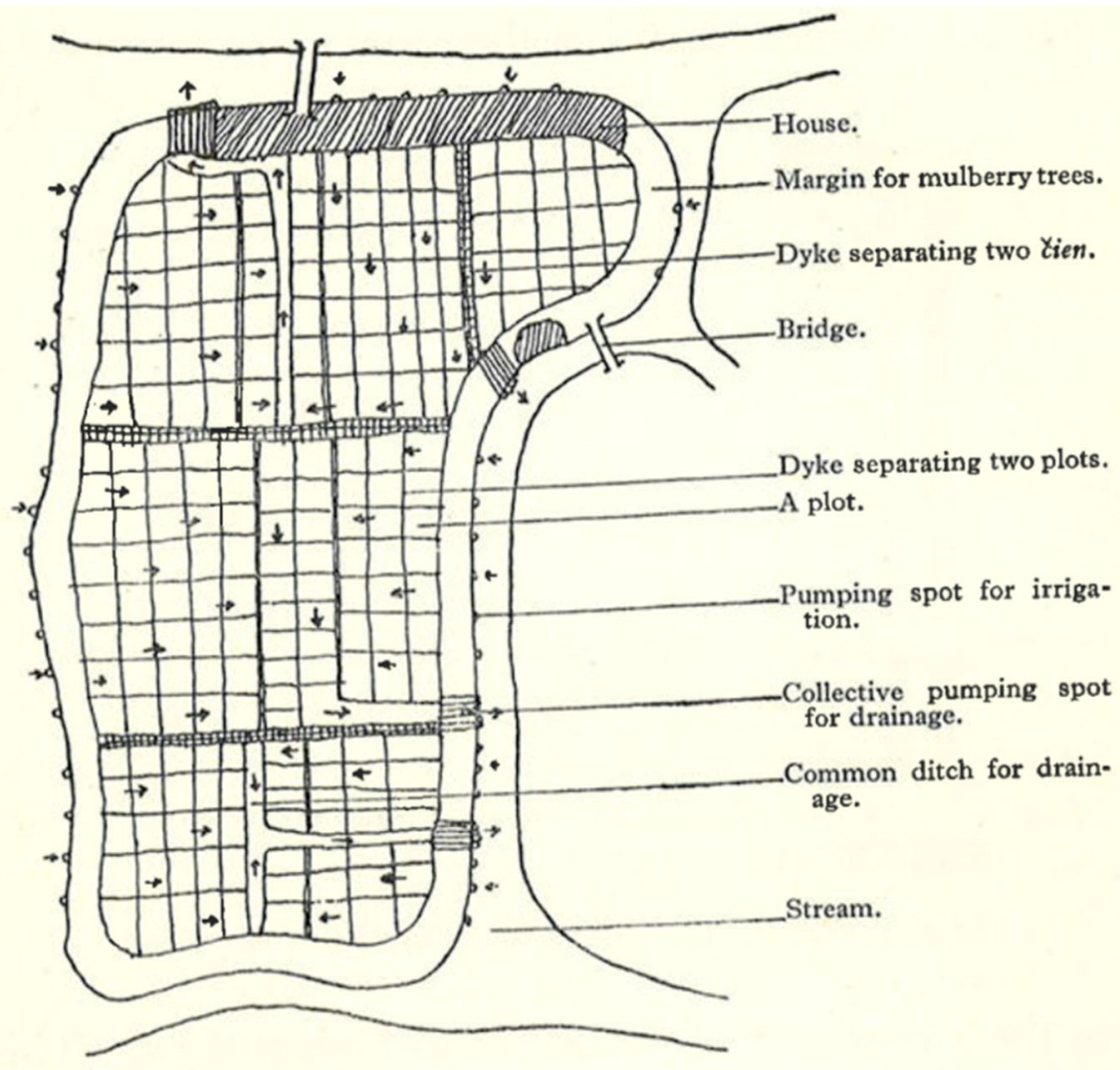

MAP IV.-Lay-out of the Farms in Hsi Chang Yu.

Fig. 13 The biggest polder in Kaihsienkung (开弦弓) village (Fei 1939, p. 157)

forced the government to cut off a large chunk of the reclaimed land from Chongming and Tongzhou, which bordered on Chongming across the Yangzi River, and set up a new Haimen Ting (海门厅) in 1768 (not the previous Haimen county, which had been dissolved in 1672) to manage the disputed newly reclaimed sandbars. ${ }^{62}$

In official narrative, the gazetteers of Chongming summarized the institutional advantage of Chongming in a series of phrases comprised of sixteen Chinese characters: sannian yizhang (三年一仗, measured by every 3 years), tanze chuliang (坍则除粮, exempted from taxes if it collapsed [into the water]), zhangze bomin (涨 则拨民, allocated to local people if [new land] emerged [from the water]), liushui weijie (流水为界, taking the running water [between sandbars] as boundary). The essential meaning of these phrases is that the land of Chongming was more regularly measured than other places; its land tax was also more flexibly adjusted; its local

\footnotetext{
${ }^{62} \mathrm{Xu}$ (2016: pp. 84-93).
} 
residents had more rights to claim newly exposed sandbars; and the boundary of the newly reclaimed lands was based on the original waterway between them. The whole system was supposed to function under the lijia system. ${ }^{63}$

However, on the ground, the land survey was controlled by a group of local experts, the so-called shazong (沙总, “sand chief”) or zhangzong (仗总, “survey chief"), whose exact background we have yet to discover. What we know from the official narrative is that these specialists possessed the crucial knowledge to draw complicate survey maps to help powerful local landowners evade tax and to control newly claimed sandbars. ${ }^{64}$

To reclaim these sandbars, considerable investments in money and labour were needed, which were in fact not mobilized via the lijia system, but by powerful local landowners. Thanks to the rich collection of the genealogies of Chongming and Haimen in the Shanghai Library, we can know some powerful local lineage like the Zhang had proclaimed they were entitled to a certain number of $t u$ (图, a taxation unit) in the lijia system and had hence monopolized all of the land allocated to these $t u$ by the seventeenth century at the latest. ${ }^{65}$ In other cases, from the same collection of genealogies, some entrepreneurial individuals ventured to develop the newly emerged sandbars between Chongming and Tongzhou and succeeded in reclaiming these elusive lands and compiled genealogy for their lineages in the eighteenth century. ${ }^{66}$ The basic procedure is that they first claimed sandbars when they were still submerged and paid taxes on them to the local government. Then, they planted some water grasses to assist the accumulation of sediment. After years of investment, they would eventually build a polder and level the soil within the embanked land. ${ }^{67}$

\subsection{State-Sponsored Reconstruction of Sea Dikes Along the Coastal Plain in the Eighteenth Century}

Back to the mainland of Jiangnan, there exist several lines of strong sand dunes along the vast coastal plain of gaoxiang, which prevented immediate danger of the invasion of the sea into the low-lying polder area of dixiang, but the storm surges, tides, and typhoons still posed grave threat to the coastal areas and rendered the tideland reclaimed there often inundated by sea water.

Throughout the Ming period, most of the sea dikes along the coast of Jiangnan were still built of earth and were often broken by the sea, but by the end of the Ming

\footnotetext{
${ }^{63}$ KXCMXZ: juan 4, “Tianzhi” 田制 [land system], pp. 6-14; and YZCMXZ: juan 7, “Tianzhi”田制 [land system], pp. 1-29.

${ }^{64}$ KXCMXZ: juan 4, “Tianzhi” 田制 [land system], pp. 6-14; and YZCMXZ: juan 7, “Tianzhi” 田制 [land system], pp. 1-29.

${ }^{65}$ ZSZP (1760): vol 1, "Zhangshi Santu Lipai Ji” 张氏三图里排记 [The discourse of the three $t u$ in the lijia system under the Zhang Lineage], pp. 107-109.

${ }^{66}$ WSZP (1797): vol 1, “Jichanggong Zhuan” 继昌公传 [The biography of the gentleman Jichang], pp. 24-27; and vol 3, "Xuepugong Zhuan," 雪固公传 [The biography of the gentleman Xuepu], pp. 2631.

${ }^{67}$ KXCMXZ: juan 4, “Tianzhi” 田制 [land system], pp. 6-14; and YZCMXZ: juan 7, “Tianzhi”田制 [land system], pp. 1-29.
} 
period, a small section of sea dikes of Jiangnan, near a custom house, Chongque (漴 阊), which was facing the strong tides of the famous Qiantang River, was buttressed by stones. That replacement was invested and designed by local people with the help of some local experts, who passed down their sea-dike-building technology within their family. ${ }^{68}$ For the rest of the sea dikes, only occasional repairing was made to make up the damage by the seas, and several sections even collapsed into the seas and the coastline was forced to retreat.

Into the Qing period, particularly into the reign of the energetic Yongzheng Emperor (1722-1735), the whole sea dike system of Jiangnan was restructured. Several major sections were replaced with stone quays, while elsewhere stone was added to reinforce the earth dikes. The imperial court paid great attention to these projects and financed it with the fund collected from the fine paid by accused officials and merchants. The expertise of the whole empire was mobilized as officials who had successful experience in other water projects of the empire were often assigned to supervise the sea dike construction of Jiangnan. As the result, the totality of the sea dikes of Jiangnan was renovated to a state-of-art standard and in some cases even beyond the real necessity. ${ }^{69}$ Against this backdrop, the whole coastline of Jiangnan was firmly defended and in the eastern tip of Jiangnan (nowadays Chuansha 川沙 and Nanhui 南汇), tideland would further silt up outside the official sea dike, and vast land was reclaimed from the sea in the nineteenth century (Fig. 14). ${ }^{70}$

\subsection{Consequences and Connections with the Jiangnan Economy}

As the land reclamation of the lower area was basically before the sixteenth century and the land reclamation on the tideland outside the sea dikes was mainly after the mid-eighteenth century, for the early modern period between circa 1600-1800, the most important land reclamation of Jiangnan actually took place in the estuary of the Yangzi River delta. The scale of that land reclamation was enormous. Chongming county, which was originally situated on a number of unstable sandbars, had become a huge island by the late seventeenth century. Nowadays, it is officially the third largest island of China (after Taiwan and Hainan). As already mentioned, in the late eighteenth century a new administrational unit, the Haimen Ting was created to administer the vast stretches of newly reclaimed and disputed sandbars between Chongming and Tongzhou.

Why was local society willing to invest in the reclamation of these sandbars on such a large scale? Without doubt, there exists an direct connection with the rise of the cotton-textile industry in Jiangnan in the sixteenth century. Most of the newly reclaimed lands were not predestined for rice cultivation. In fact, the newly acquired soil was not even suitable for paddy cultivation, as it was too sandy and too salty. But it was suitable for cotton cultivation, the early nineteenth edition of the gazetteer of Haimen Ting notes, "present day throughout the territory of Haimen,

\footnotetext{
${ }^{68}$ Feng (2008: pp. 178-183).

69 Wang (2007a: pp. 116-136, 2008: pp. 58-69, 2007b).

70 Wang (2007b: pp. 151-170).
} 


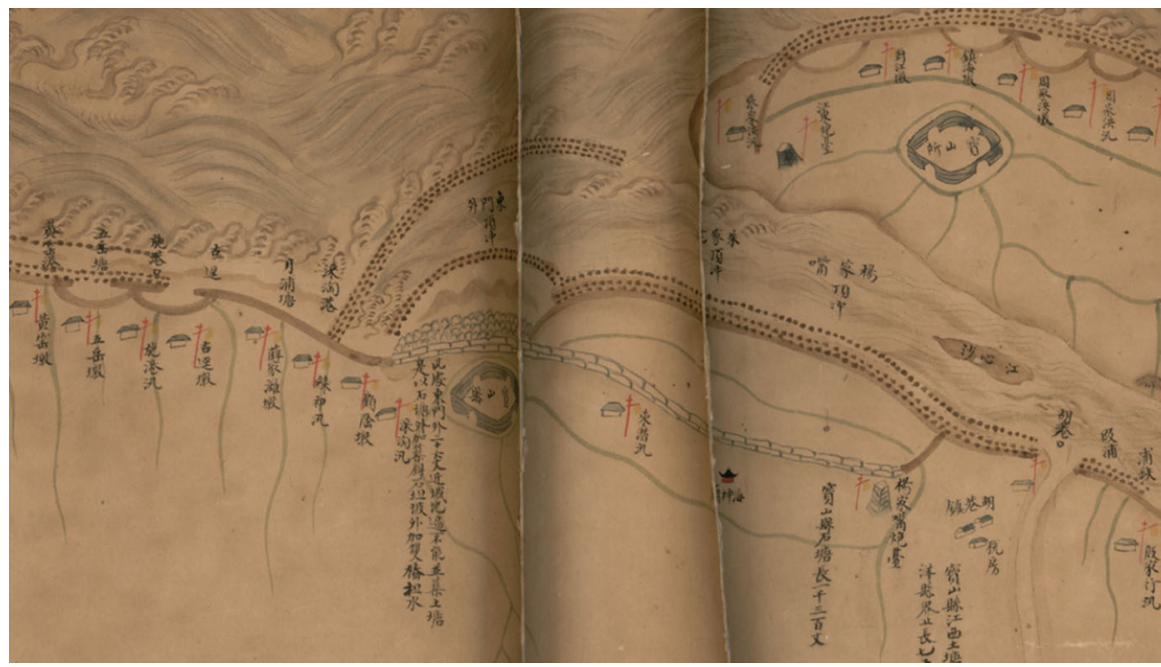

Fig. 14 Detail from “Jiangnan hai tang tu” 江南海塘图 [Map of the Jiangnan Seawall], drawn between 1750 and 1753. There were three lines of a combined sea dike system at the critical intersection between the Yangzi River and the Huangpu River. The strongest and most costly part was the stone levee, outside of which there was an earthen dike. On the seaward side of the earthen dikes, there were several lines of wood piles. When the stone levee abutted the water directly because sufficient space was lacking to build an earthen dike, a stone slope, supported by two lines of wood piles, was built on the waterside. (Library of Congress (call number G7823.J48N22.1795.S6, Vault Shelf AACR2); https://www.loc.gov/resource/ g7823j.ct003416/, accessed 17 October 2017)

80-90\% land was cultivated with cotton and only 10-20\% was with rice". ${ }^{71}$ Ironically Chongming, with its vast reclaimed sandbars, even became a desperate rice-shortage region by the eighteenth century. Since 1714, it was allowed to import 220,000 piculs of rice annually from the upriver of the Yangzi River. The annual quota was increased over time so that by 1789 it had reached 370,000 piculs. For this purpose, 100 ships were granted special licences to purchase rice from upriver places. $^{72}$ At the same time, this region also became a major production area of cotton which was shipped to Jiangnan, North China and Manchuria. With the help of cotton and textile, the flat-bottomed sand ship (沙 船) owners from Chongming became the dominant carriers in the North China Sea trade between Jiangnan, North China, and Manchuria in the eighteenth and nineteenth centuries. ${ }^{73}$

\footnotetext{
71 JQHMTZ: juan 2, "Yudi" 舆地 [Geography].

72 MGCMXZ: juan 7, “Caimai” 采买 [Purchase], 29.

73 Matsuura (2010).
} 


\section{Comparisons}

The geological setting of the Rhine River delta and the Yangzi River delta was more or less similar, but the ecological challenges manifested in each region were quite different. In general, the Yangzi delta faced less challenges and more advantage. First, it did not have extensively developed peat land, and hence, the reclaimed marshland was not subject to such persistent and dramatic subsidence as the drying up peat lands in the Rhine delta. Second, it had a more developed and larger sand dune area. These strong dune ranges, on the one hand, protected the lower-lying inner polder area from the encroachment of the sea, but on the other hand, they also rendered an extra hindrance to Jiangnan because they blocked the outflow of the water drained from the inner polder land to the sea. In comparison, the coastal sand dunes in the Netherlands were often much weaker and occasionally could not protect the polder areas directly to the sea as was the case in late medieval Zeeland and was the case when facing the outbreak of shipworms. Third, the estuary of the Yangzi River provided a much richer supply of river and marine sediment from up and nearby rivers. Particularly, the Yellow River whose outlet to the sea had moved to the same sea shared by the estuary of the Yangzi River since the twelfth century provided plenty of silt and caused the sandbars in the Yangzi River estuary to grow much faster, enabling local entrepreneurs to embank them with much more efficiency.

At the same time, it cannot be denied that the Rhine River delta had institutional and technological advantages. First of all, it could boast of advanced networks of knowledge and know-how and various interconnected technological breakthroughs, such as the newly designed windmills and the surveyed land maps with the help of triangulation. Fairly speaking, the crisis of the polder area in Jiangnan was only relieved by reorganizing the relation between landowners and tenants and by dividing large polders into small polders. The basic technology was still the same as the Song period, for instance, the foot-pedal watermill (脚踏翻车) remained the only tool to drain water from polders. Hardly any substantial land reclamation happened in this area of Jiangnan in the early modern period. Financial institutions to encourage such large-scale investments by the urban class in Jiangnan were also lacking.

The creation of the chartered joint stock companies in collusion with the licenceissuing government like the East and West India Companies was not an isolated event in early modern Dutch history. The same procedure was followed in the case of land reclamation. In both North Holland and the estuary of the Rhine River, investors from the cities obtained exclusive rights from the government and organized companies to reclaim designated submerged land. Their investments were fortified by the advanced cartographic technology and the institutionally trained land surveyors, who could make relatively reliable maps to divide land into different shares and to attract more urban investors. This kind of investment never occurred in early modern Jiangnan.

What also lacked in Jiangnan was the process of the communalization of the local polder management boards. As argued by Hamashima Atsutoshi (滨岛敦俊), there 
existed no regional water management boards in the polder area of Jiangnan. The cooperation among the different owners in a Chinese polder was based on their immediate urgency and was not coordinated by a higher level of communalized water boards as in the Netherlands. It might have been subject to lijia system in the early Ming period, but when that system collapsed in the mid-Ming period, the management of big polders became difficult. It seems the division of polders into smaller units to some extent relieved the mounting crisis in the management of the older large-polder system, as Jiangnan lacked the Dutch Republic's technological and institutional innovations to drain water in a coordinated and large-scale way. Small polders could be easily managed by fewer owners who have a common interest in the same polder. However, in the Rhine River delta, local water authorities had already been regulated as early as the high medieval period (eleventh to thirteenth centuries). These organizations were represented by the landowners within a particular polder or several connected polders. They decided on the execution of dike maintenance and water drainage. Into the late medieval period, and particularly into the sixteenth and seventeenth centuries, above these local water boards, the large regional water authorities, the so-called hoogheemraadschap, obtained supreme power to employ professional land surveyors to "scientifically" manage water drainage. These water boards have preserved their archives very well up to the present, and these offer the historian wonderful local documents for the understanding of the process of the communalization of local water boards in the North and South Holland.

In China, we see developments occurring in the other directions: In the estuary area of the Yangzi River, power and knowledge were increasingly localized. Lineages, which were an institutional invention in the sixteenth-century China, began to play increasing roles in the land reclamation in the sandbars of Chongming and Haimen since the seventeenth century. From the genealogies collected by the Shanghai Library, it is clear that a large number of land investors in Chongming began to compile genealogies starting in the late seventeenth century and early eighteenth century. The constructed lineage organizations had an interesting link with the investment and management of the massively reclaimed sandbars in the estuary of the Yangzi River, which deserves more discussion. Meanwhile, the expertise of land survey and water drainage was not taught in any officially organized programme at a higher institution of learning, but was passed down by the so-called shazong ("sand chief"), whose expertise competed with the daily functions of the local government and therefore stood in ill repute with the officials: These local experts knew how to draw complex maps to help landowners evade taxes, since the local government lacked the skill to understand the maps. It is apparent that land reclamation in the estuary slipped away from the control of the government and into the hands of the local lineages and experts.

Nonetheless, there remained an interesting commonality between the Dutch Republic and Jiangnan, namely the innovation of building sea dikes and the role of the state in this process. Almost simultaneously, around the 1730s, the Dutch Republic and the Qing Empire began to use more durable material, that is, stone, to reinforce the old wood and earth structures. The investment and renovation made in Jiangnan by the Qing Empire likely transcended that of the Dutch Republic, since it 
often replaced entire earth dikes with stone instead of only replacing wooden piles with stone material on the seaward side. An interesting connection was that when some Dutch engineers, such as Hendrik de Rijke, were invited to organize the improvement of a water project in the Yangzi River delta in the early twentieth century, they found they could still learn a lot from Chinese traditional sea-dikebuilding techniques. ${ }^{74}$

\section{Conclusion}

Facing more or less similar ecological challenges and constraints, the Rhine River delta and the Yangzi River delta developed along completely divergent ways in the early modern period. It is hard to judge which was more efficient, but whereas the development in the Rhine River delta was characterized by technological and institutional breakthroughs and the communalization of local water management organization, the development in the Yangzi River delta showed increasing localization of land reclamation, which was at certain points along the coast supported by strong state intervention. As a result, the Dutch were better equipped to deal with major innovation works when the industrial revolution set in, although it also took them some time before they were willing and able to put steam energy to use in the case of the Haarlemmermeer drainage project. ${ }^{75}$ But without doubt, institutionally speaking everything that was required for a nationally organized water management organization for coordinating large projects was available. In the nineteenth century, all water boards in the Netherlands were subordinated to the national ministry of Waterstaat, indeed a water state within the state.

This exploratory essay has only skimmed the huge potential of the comparative studies of the hydraulic works in the two riverine societies of the Rhine and Yangzi. We hope that further historical research will be carried out to examine more specialized sub-regional comparisons such as those sand dunes, lower land, sandbars, and sea dikes, and, equally important, thematic comparisons of technological change, institutional development, the spread of knowledge, and, in general, the perceived culture of water/landscape. If this paper has raised an interest in these issues, we feel we have reached our aim.

Open Access This article is distributed under the terms of the Creative Commons Attribution 4.0 International License (http://creativecommons.org/licenses/by/4.0/), which permits unrestricted use, distribution, and reproduction in any medium, provided you give appropriate credit to the original author(s) and the source, provide a link to the Creative Commons license, and indicate if changes were made.

\footnotetext{
74 Sizoo (2005: pp. 36-37).

75 Tielhof and van Dam (2006b, pp. 164-169, 261-273). Van Tielhof and van Dam add another argument why the reclamation of the Haarlemmermeer took such a long time to be carried out. The lake originally served as a reservoir for the Rhineland Water Authorities. Not until a new opening to the sea was created at Katwijk in 1807 and big pumps had been installed to replace the buffering capacity of the lake, reclamation plans could take shape. Furthermore, the cities of Haarlem and Leiden mounted opposition because they would lose their fishing grounds.
} 


\section{References}

\section{Dutch and English}

Borger, G.J. 1988. De bedreiger bedreigd. De wisselwerking tussen menselijke invloed en natuurlijke processen in de bewoningsgeschiedenis van een waterrijk gebied. Bijdragen en Mededelingen betreffende de Geschiedenis der Nederlanden (MBGN) 103(4): 522-533.

Brusse, Paul. 2017. Res publica in de Republiek. Onderzoek naar participatie in het plaatselijk waterbeheer en in de dorpsbesturen in het Gelders rivierengebied, 1650-1795. Bijdragen en Mededelingen Gelre 108: 91-119.

Cheng, Wei-chung 郑维中. 2012. "War, Trade and Piracy in the China Seas (1622-1683)." PhD diss., Leiden University.

Ciriacono, Salvatore. 2008. Water control: A network of knowledge and know-how. In Water and state in Europe and Asia, ed. Peter Borschberg, and Martin Krieger, 239-256. New Delhi: Manohar.

Davids, Karel. 2012. Religion, Technology, and the Great and Little Divergences: China and Europe compared, c. 700-1800 (History of Science and Medicine Library 32; Knowledge Infrastructure and Knowledge Economy, 2). Leiden: Brill.

Davids, Karel. 2008. The Rise and Decline of Dutch Technological Leadership. Technology, Economy and Culture in the Netherlands, 1350-1800. 2 vols. Leiden: Brill. Section on land and water, vol. 1.

de Vries, Jan, and Ad van der Woude. 1997. The First Modern Economy: Success, Failure, and Perseverance of the Dutch Economy, 1500-1815. Cambridge: Cambridge University Press.

de Vries, Jan. 2008. The Industrious Revolution: Consumer Behavior and the Household Economy. 1650to the Present. New York: Cambridge University Press.

Fei, Hsiao-tung 费孝通. 1939. Peasant Life in China: A Field Study of Country Life in the Yangtze Valley. London: Routledge.

Fleischer, Alette. 2007. "The Beemster Polder: Conservative Invention and Holland's Great Pleasure Garden." In The Mindful Hand: Inquiry and Invention from the Late Renaissance to Early Industrialisation, ed. Lissa L. Roberts, Simon Schaffer, and Peter Dear, 145-166. Publishing House of the Royal Netherlands Academy of Arts and Sciences.

Giebels, Ludy (ed.). 1988. Waterbeweging rond Gouda van ca. 1100 tot heden. Leiden: Hoogheemraadschap van Rijnland.

Hamashima, Atsutoshi 滨岛敦俊. 1980. The organization of water control in the Kiangnan Delta in the Ming Period. Acta Asiatica 38: 69-76.

Henderikx, P.A. 1988. Waterbeheersing en afwatering in de Alblasserwaard tot de invoering van de bemaling in de vijftiende eeuw. BMGN 103-104: 554-570.

Jeurgens, Charles. 1991. "De Haarlemmermeer: een studie in planning en beleid, 1836-1858." Ph.D. dissertation, Leiden University.

Kaptein, Herman. 2017. Nijverheid op wind kracht: Energie-transities in Nederland, 1500-1900. Hilversum: Verloren.

Koopmans, Joop W. 2016. The Early 1730s Shipworm Disaster in Dutch News Media. Dutch Crossing: Journal of Low Countries Studies 40(2): 139-150.

Pouls, H.C. 1997. De landmeter: Inleiding in de geschiedenis van de Nederlandse landmeetkundevan de Romeinse tot de Franse tijd. Alphen aan den Rijn: Canaletto/Repro-Holland.

Pouls, H.C. 2004. De landmeter Jan Pietersz. Dou en de Hollandse Cirkel. Delft: Nederlandse Commissie voor Geodesie.

Shiba, Yoshinobu 斯波义信. 2011. The Diversity of the Socio-Economy in Song China, 960-1279. Tokyo: The Toyo Bunko.

Sizoo, Koen. 2005. Johannis and Hendrik de Rijke: Two Dutch Engineers in the Yangtze Delta, trans. Li Xiansheng. Beijing: The Royal Nederlands Embassy in Beijing.

Steenbergen, Clemens, Wouter Reh, Steffen Nijhuis, and Michiel Pouderoijen. 2009. The Polder Atlas of the Netherlands. Bussum: THOTH Publishers.

Sundberg, Adam D. 2015. "Floods, Worms, and Cattle Plague: Nature-induced Disaster at the Closing of the Dutch Golden Age, 1672-1764.” PhD diss., University of Kansas

van Cruyningen, Piet. 2006. "Profits and Risks in Drainage Projects in Staats-Vlaanderen, c. 1590-1665". In Water Management, Communities, and Environment. The Low Countries in Comparative 
Perspective, c. 1000-c. 1800. edited by Hilde Greefs and Marjolein't Hart, 123-142. Gent: Academia Press.

van Cruyningen, Piet. 2014. From disaster to sustainability: Floods, changing property relations and water management in the South-western Netherlands, c. 1500-1800. Continuity and Change 29(2): 241265.

van Cruyningen, Piet. 2015. Dealing with drainage: State regulation of drainage projects in the Dutch Republic, France, and England during the sixteenth and seventeenth centuries. Economic History Review 68(2): 420-440.

van Dam, Petra J.E.M. 2001. Sinking peat bogs: Environmental change in Holland, 1350-1550. Environmental History 6(1): 32-45.

van Tielhof, Milja. 2015. Forced solidarity: Maintenance of Coastal Defences Along the North Sea Coast in the Early Modern Period. Environment and History 21(3): 319-350.

van Tielhof, Milja. 2017. Regional Planning in a Decentralized State: How Administrative Practices Contributed to Consensus-Building in Sixteenth-Century Holland. Environment and History 23(3): 431-453.

van Tielhof, Milja, and Dam, Petra van. 2006a. "Losing Land, Gaining Water. Ecological and Financial Aspects of Regional Water Management in Rijnland, 1200-1800". In Water Management, Communities, and Environment. The Low Countries in Comparative Perspective, c. 1000-c. 1800, ed. Hilde Greefs and Marjolein't Hart, 63-94. Gent: Academia Press.

van Tielhof, Milja, and Dam, Petra van. 2006b. Waterstaat in stedenland. Het hoogheemraadschap van Rijnland voor 1857. Utrecht: Matrijs.

van de Ven, G.P. (ed.). 2003. Leefbaar laagland: Geschiedenis van de waterbeheersing en landaanwinning in Nederland. Utrecht: Matrijs.

van de Ven, G.P. (ed.). 2004. Man-made Lowlands. History of Water Management and Land Reclamation in the Netherlands. Utrecht: Matrijs.

Wareham, Andrew. 2006. "Water Management and the Economic Environment in Eastern England, the Low Countries and China c. 960-1650: Comparisons and Consequences." In Water Management, Communities, and Environment. The Low Countries in Comparative Perspective, c. 1000-c. 1800, ed. Hilde Greefs and Marjolein't Hart, 9-34. Gent: Academia Press.

Wieringa, Frouke. 1994. Landmeters in de Beemster, de Purmer en de Wormer. In Perfect gemeten: Landmeters in Hollands noorderkwartier, ed. Chris Streefkerk, Jan Werner, and Frouke Wieringa, 57-67. Wormerveer: Stichting Uitgeverij Noord-Holland.

$\mathrm{Xu}$, Guanmian 徐冠勉. 2017. “The Making of Sino-Dutch Sugar Frontiers in Early Modern Asia: Connections and Comparisons, 1630s-1730s." MA thesis, Leiden University.

Zeischka, Siger. 2006. "Dealing with Diversity: Small-Scale Dikes in Early Modern Rijnland, 17th-Early 19th Century." In Water Management, Communities, and Environment. The Low Countries in Comparative Perspective, c. 1000-c. 1800, ed. Hilde Greefs and Marjolein't Hart, 175-94. Gent: Academia Press.

\section{Chinese and Japanese}

Fan, I-chun 范毅军. 2005. Chuantong Shizhen yu Quyu Fazhan - Mingqing Taihu yidong Diqu Weili, 1551-1861 传统市镇与区域发展 - 明清太湖以东地区为例, 1551-1861 [Traditional market and regional development - the region east of Lake Tai as an example, 1551-1861]. Taipei: Academia Sinicia.

Feng, Yurong 冯玉荣. 2008. “Mingmo Qingchu Shehui Biandong yu Haitang de Xiuzhu - Yi Chongque Haitang wei Zhongxin” 明末清初社会变动与海塘的修筑——以漴缺海塘为中心 [The social change during the end of Ming and the beginning of Qing and its relation with the construction of sea dikes - With Chongque seadike as the centre]. Nongye Kaogu 4(2008): 178-183.

Hamashima, Atsutoshi 滨岛敦俊. 1982. Mindai Kōnan nōson shakai no kenkyū 明代江南農村社会の研 究 [Rural Society in Jiangnan during the Ming Dynasty]. Tokyo: Tokyo University Press.

Hamashima, Atsutoshi 滨岛敦俊. 1989. “Tudi Kaifa yu Keshang Huodong-Mingdai Zhongqi Jiangnan Dizhu zhi Touzi Huodong” 土地开发与客商活动一明代中期江南地主之投资活动 [Land development and the activities of nonlocal merchants - the investment activities of the landlords of Jiangnan during the mid-Ming]. In Zhongyang Yanjiuyuan Di Erjie Guoji Hanxue Huiyi Lunwen Ji, 
Mingqing yu Jindai Shizu, Shangce 中央研究院第二届国际汉学会议论文集, 明清与近代史组, 上册, 101-122. Taipei: Academia Sinicia.

Liao, Qiyu 繆启愉. 1985. Taihu Tangpu Weitian Shi Yanjiu 太湖塘浦圩田史研究 [The research of the dikes and polders of Lake Tai]. Beijing: Nongye Chubanshe.

Matsuura, Akira 松浦章. 2010. Shindai hansen enkai kōunshi no kenkyū 清代帆船沿海航运史の研究 [The studies of the coastal shipping of the Qing dynasty]. Suita-shi: Kansai Daigaku Shuppanbu.

Wang, Daxue 王大学. 2007a. "Huangquan, Jingguan yu Yongzheng Chao de Jiangnan Haitang Gongcheng” 皇权、景观与雍正朝的江南海塘工程 [Imperial power, sights and seawall project in the south of the Yangzi River under the reign of Yongzheng Emperor]. Shilin 4 (2007): 116-136.

Wang, Daxue 王大学. 2008. “Zhengling, Shiling, yu Jiangnan Haitang Beiduan Gongcheng” 政令、时 令与江南海塘北段工程 [Government order, seasonal regulations and the northern part of coastal engineering of Jiangnan area]. Shilin 5 (2008): 58-69.

Wang, Daxue 王大学. 2007b. “Mingqing Jiangnan Haitang de Jianshe yu Huanjing” 明清江南海塘的建 设与环境 [The construction and environment of the sea dikes of Jiangnan during the Ming-Qing period]. PhD diss., Fudan University.

Wang, Jiange 王建革. 2011. "Mingdai Jiangnan de Shuili Danwei yu Difang Zhidu: Yi Changshu Wei Li” 明代江南的水利单位与地方制度：以常熟为例 [The water management unit and local institution of Jiangnan during the Ming period: Using Changshu as an example]. Zhongguoshi Yanjiu 2 (2011): 165-179.

Wu, Tao 吴滔. 2012. "Haiwai zhi Bianti: Mingqing Shiqi Chongming Yanchang Xingfei yu Quyufazhan" 海外之变体：明清时期崇明盐场兴废与区域发展 [The ups and downs of Chongming's saltern and regional development in the Ming and Qing dynasty]. Xueshu Yanjiu 5 (2012): 105-114.

Wu, Tao 吴滔. 2006. “Mingqing Jiangnan Jiceng Quhua de Chuantong yu Shizhen Bianqian” 明清江南 基层区划与市镇变迁 [Demarcation of Grassroots Districts and the Evolution of Cities and Towns in the Jiangnan Area during the Ming and Qing Dynasties: with Suzhou as an Example]. Lishi Yanjiu 5 (2006), 51-71.

Xie, Shi 谢湜. 2010. “11 Shiji Taihu Diqu Nongtian Shuili Geju de Xingcheng” 11 世纪太湖地区农田水 利格局的形成 [The formation of water management system in the farmland of the Lake Tai region in the eleventh century]. Journal of Sun Yat-sen University 50:5 (2010): 94-106.

Xie, Shi 谢湜. 2015. Gaoxiang yu Dixiang: 11-16 Shiji Jiangnan Quyu Lishi Dili Yanjiu 高乡与低乡: 1116 世纪江南区域历史地理研究 [Gaoxiang and dixiang: Study of the historical geography of Jiangnan region from 11th-16th centuries]. Beijing: SDX Joint Publishing Company.

Xie, Shi 谢湜. 2012a. "Shiwu, Shiliu Shiji Jiangnan Fuyi Gaige yu Huangdi Wenti” 十五、十六世纪江 南赋役改革与荒地问题 [Models for development or institutional Characteristics?-The reform of the tax system and land reclamation in the Lower Yangtze Delta in the 15th and 16th centuries]. Bulletin of the Institute of History and Philology Academia Sinica 83:2 (2012): 349-354.

Xie, Shi 谢湜. 2012b. “Zhi yu Buzhi: 16 Shiji Jiangnan Shuili de Jizhi Kunjing Jiqi Tiaoshi” 治与不治: 16 世纪江南水利的机制困境及其调适 [To do or not to do: The predicament of water management system in sixteenth century Jiangnan and its adjustment]. Хиеshu Yапjiи 9 (2012): 109-119.

Xu, Feng 徐枫. 2016. "Cong Taitong Dao dao Haimen Ting: Yongqian Shiqi Changjiang Kou Shawu Guanli Jigou de Bianqian”从太通道到海门厅: 雍乾时期长江口沙务管理机构的变迁 [Evolution of the administrative institution for sand affairs in the Yangtze River estuary during the reigns of Yongzheng and Qianlong]. Shilin 1 (2016): 84-93.

Zhang, Fang 张芳. 1985. “Geng Ju and Changshu Xian Shuili Quanshu” 耿桔和《常熟县水利全书》 [Geng Ju and the complete guidance of the water management of Changshu county]. Zhongguo Nongshi 3 (1985): 64-73.

\section{Chinese Primary Sources: Gazetteers}

JQHMTZ (Jiaqing Haimen Tingzhi). 嘉庆海门厅志 [The Jiaqing edition of Haimen Gazetteer].

KXCMXZ (KangxiChongming Xianzhi). 康熙崇明县志 [The Kangxi edition of Chongming Gazetteer]. MGCMXZ (Minguo Chongming Xianzhi). 民国崇明县志 [The Republic edition of Chongming Gazetteer].

YZCMXZ (Yongzheng Chongming Xianzhi). 雍正崇明县志 [The Yongzheng edition of Chongming Gazetteer]. 


\section{Genealogies}

WSZP (Wushi Zongpu). 吴氏宗谱[崇明]嘉庆 2 年 [The Genealogy of Wu] (1797), The genealogy collection of Shanghai Library, call number: 2093/A, 上海图书馆家谱数据库, 索取号 2093/A.

ZSZP (Zhangshi Zongpu). 张氏宗谱[崇明] 乾隆 25 年 [The Genealogy of Zhang] (1760), The genealogy collection of Shanghai Library, call number: 1156, 上海图书馆家谱数据库, 索取号 1156.

Guanmian Xu 徐冠勉 is a Ph.D. candidate at the Leiden University Institute for Area Studies (LIAS). His Ph.D. project is generously sponsored by the Ph.D. fellowship of the Hulsewé-Wazniewski Foundation in Leiden.

Leonard Blussé is Professor Emeritus in the History of European-Asian Relations at the Leiden University Institute for History (chair from 1998 to 2011). 